\title{
Measure Guideline: Combined Space and Water Heating Installation and Optimization
}

B. Schoenbauer, D. Bohac, and P. Huelman NorthernSTAR 


\section{NOTICE}

This report was prepared as an account of work sponsored by an agency of the United States government. Neither the United States government nor any agency thereof, nor any of their employees, subcontractors, or affiliated partners makes any warranty, express or implied, or assumes any legal liability or responsibility for the accuracy, completeness, or usefulness of any information, apparatus, product, or process disclosed, or represents that its use would not infringe privately owned rights. Reference herein to any specific commercial product, process, or service by trade name, trademark, manufacturer, or otherwise does not necessarily constitute or imply its endorsement, recommendation, or favoring by the United States government or any agency thereof. The views and opinions of authors expressed herein do not necessarily state or reflect those of the United States government or any agency thereof.

This report is available at no cost from the National Renewable Energy Laboratory (NREL) at www.nrel.gov/publications.

Available electronically at SciTech Connect http:/www.osti.gov/scitech

Available for a processing fee to U.S. Department of Energy and its contractors, in paper, from:

U.S. Department of Energy

Office of Scientific and Technical Information

P.O. Box 62

Oak Ridge, TN 37831-0062

OSTI http://www.osti.gov

Phone: 865.576.8401

Fax: 865.576.5728

Email: reports@osti.gov

Available for sale to the public, in paper, from:

U.S. Department of Commerce

National Technical Information Service

5301 Shawnee Road

Alexandria, VA 22312

NTIS http://www.ntis.gov

Phone: 800.553 .6847 or 703.605 .6000

Fax: 703.605.6900

Email: orders@ntis.gov 


\title{
Measure Guideline: Combined Space and Water Heating Installation and Optimization
}

\author{
Prepared for: \\ The National Renewable Energy Laboratory \\ On behalf of the U.S. Department of Energy's Building America Program \\ Office of Energy Efficiency and Renewable Energy \\ 15013 Denver West Parkway \\ Golden, CO 80401 \\ NREL Contract No. DE-AC36-08GO28308 \\ Prepared by: \\ B. Schoenbauer, D. Bohac, and P. Huelman \\ NorthernSTAR Building America Partnership \\ University of Minnesota \\ 2004 Folwell Avenue \\ St. Paul, MN 55108 \\ NREL Technical Monitor: Stacey Rothgeb \\ Prepared under Subcontract No. KNDJ-0-40338-05
}

March 2017 
The work presented in this report does not represent performance of any product relative to regulated minimum efficiency requirements.

The laboratory and/or field sites used for this work are not certified rating test facilities. The conditions and methods under which products were characterized for this work differ from standard rating conditions, as described.

Because the methods and conditions differ, the reported results are not comparable to rated product performance and should only be used to estimate performance under the measured conditions. 


\section{Contents}

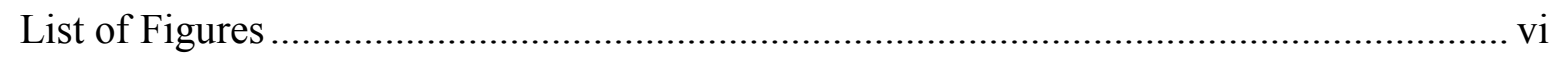

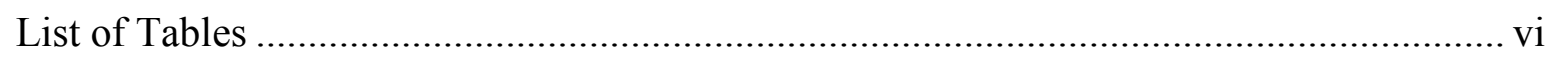

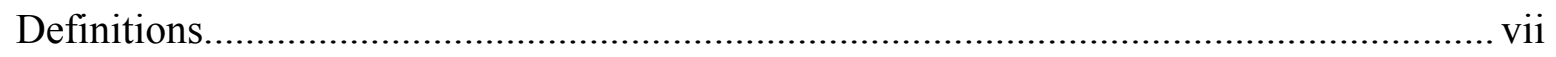

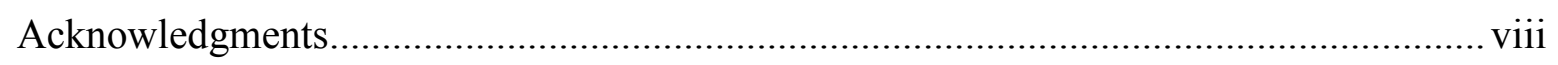

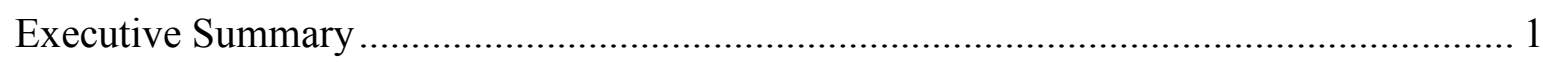

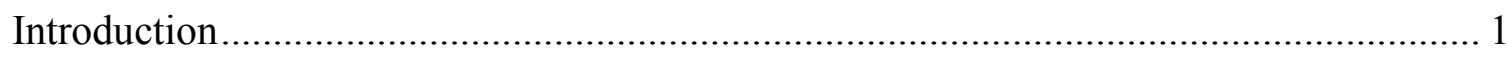

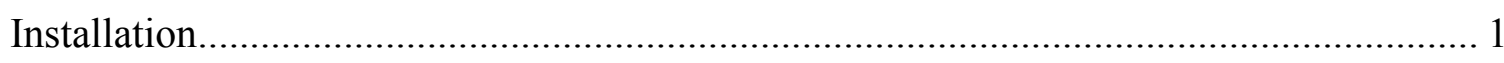

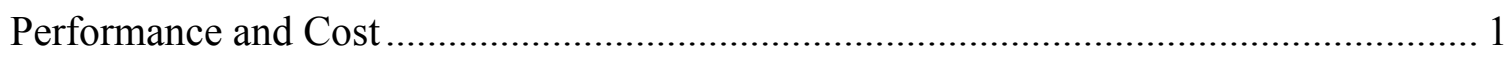

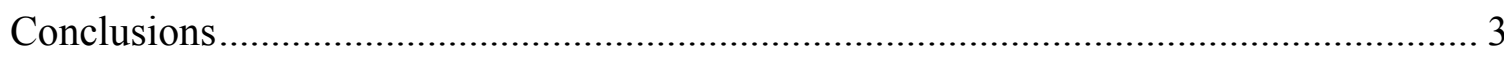

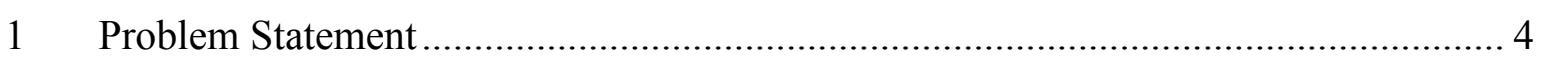

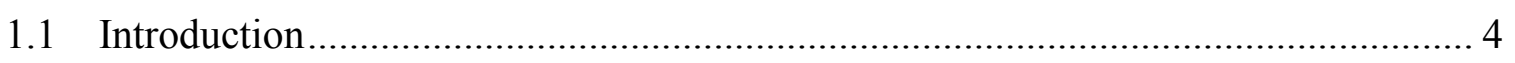

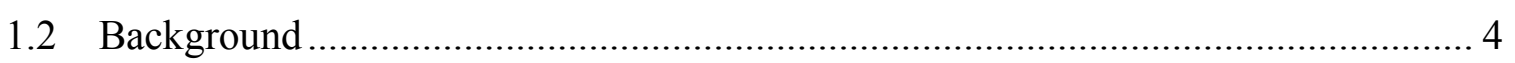

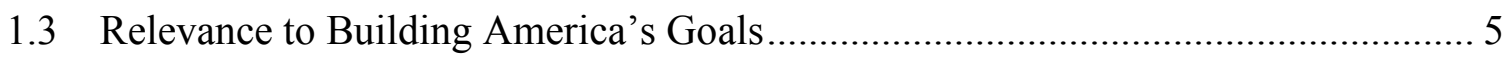

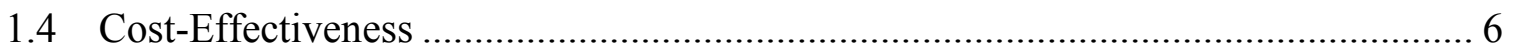

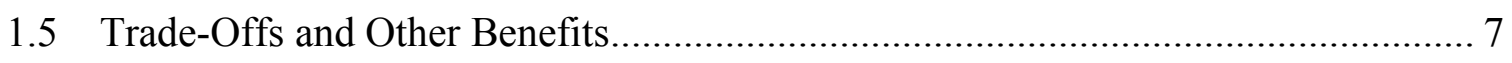

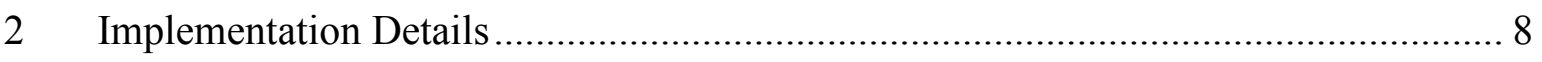

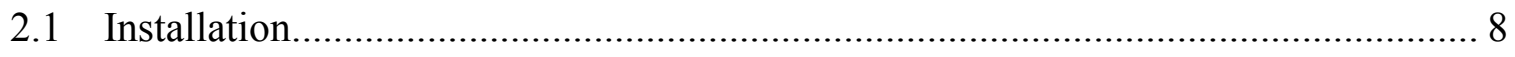

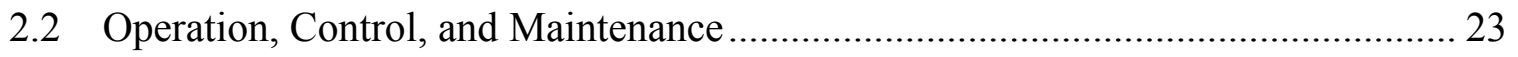

2.3 Metrics and Standards (Ensuring Performance) ……………………................... 25

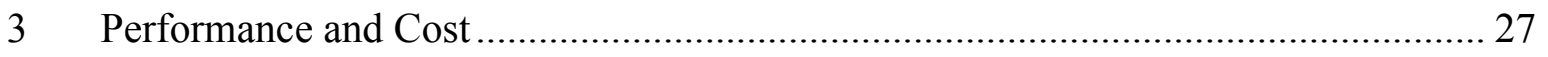

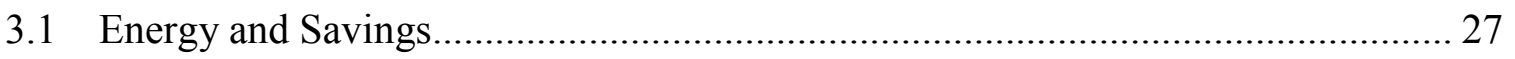

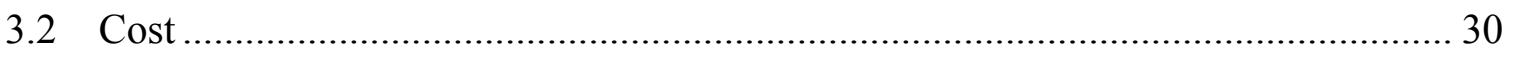

3.3 Delivered Performance ………………………........................................... 32

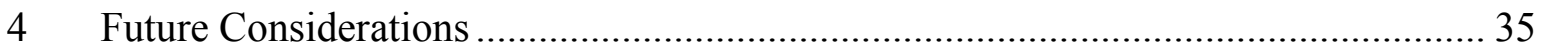

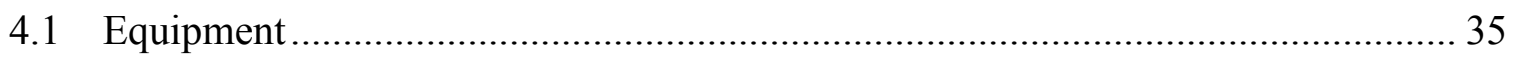

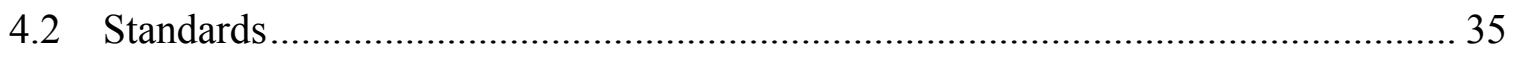

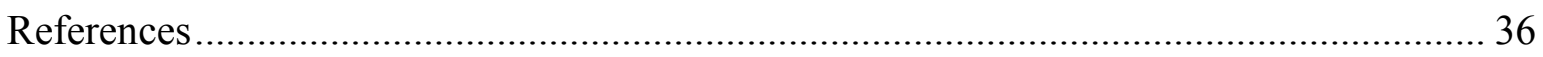




\section{List of Figures}

Figure A. Installation costs for residential heating, ventilating, and air-conditioning systems ......... 2

Figure 1. Sample heating-load calculations for Minnesota homes......................................................

Figure 2. Forced-air combination systems using open loops and potable AHUs ...........................12

Figure 3. Comparison before and after installation......................................................................13

Figure 4. Example of combi system sizing for a two-bathroom home in a cold climate...................15

Figure 5. Single-wall water heater and furnace vents replaced with direct vent system ..................16

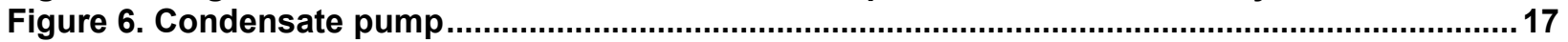

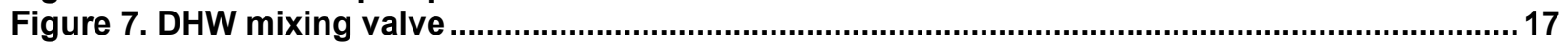

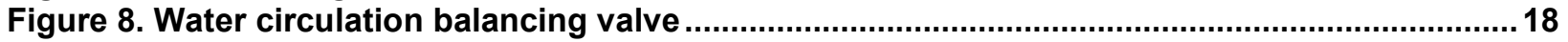

Figure 9. Impact of return water temperature on combi system efficiency under space heating

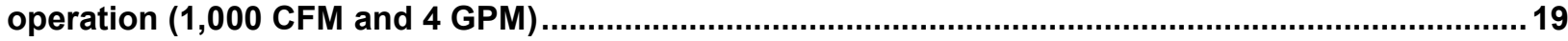

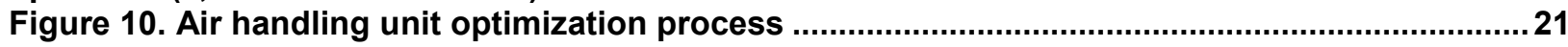

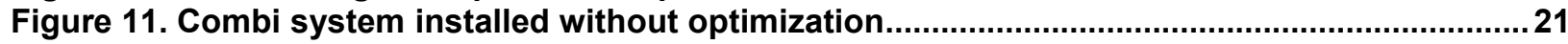

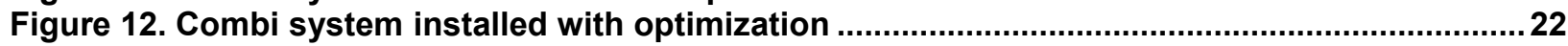

Figure 13. Combi system installed fully optimized .................................................................2

Figure 14. Hot water temperatures delivered by the water heater (black) and mixing value (blue). 24

Figure 15. Energy savings from combi systems monitored in real homes ...................................28

Figure 16. Infrared images of a (clockwise from top) CStWH, HWH, and CTWH in standby mode.. 29

Figure 17. Seasonal operating efficiency of combi and traditional heating systems........................30

Figure 18. Installation costs for residential heating, ventilating, and air-conditioning systems ......32

Figure 19.Time series discharge air temperatures for combi systems ...........................................33

Figure 20.Time series DHW outlet temperatures for combi systems ............................................... 34

\section{List of Tables}

Table A. Average Installed Performance of Combi Systems in 11 Homes ...................................... 1

Table 1. Sample Heating Plants That Can Be Used for Combi Systems ........................................11

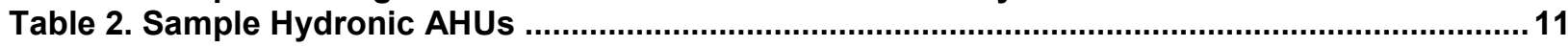

Table 3. Benefits and Drawbacks of Heating Plant Selection .....................................................13

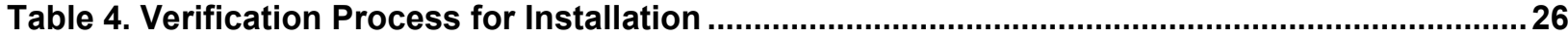

Table 5. Average Installed Performance of Combi Systems in 11 Homes .....................................28

Table 6. Average Installation Costs from Implementation Project ......................................................30

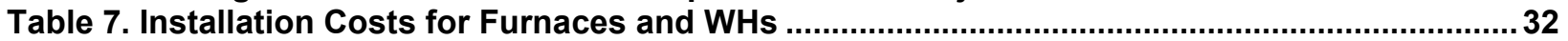




\section{Definitions}

$\begin{array}{ll}\text { AFUE } & \text { annual fuel utilization efficiency } \\ \text { AHU } & \text { air handling unit } \\ \text { BA } & \text { Building America Program } \\ \text { Combi } & \text { combined space and water heating system } \\ \text { cfm } & \text { cubic feet per minute } \\ \text { CStWH } & \text { condensing storage water heater } \\ \text { CTWH } & \text { condensing tankless water heater } \\ \text { DHW } & \text { domestic hot water } \\ \text { EF } & \text { energy factor } \\ \text { gpm } & \text { gallons per minute } \\ \text { HWH } & \text { hybrid water heater } \\ \text { NEAT } & \text { National Energy Audit Tool } \\ \text { StWH } & \text { storage water heater } \\ \text { TWH } & \text { tankless water heater }\end{array}$




\section{Acknowledgments}

This report was prepared for the U.S. Department of Energy Building America Program (BA). Funding for this work was provided by the National Renewable Energy Laboratory under contract KNDJ-0-40338-02. Additional funds to support this work were provided by the Weatherization Assistance Program through a grant from Sustainable Energy Resources for Consumers, the Center for Energy and Environment, and the Energy Conservatory. Additional support through loaned or donated equipment was provided from Rinnai, A.O. Smith Corporation, American Water Heaters, Eternal, Heat Transfer Products, Navien American, Enerzone, Life Breath, NuAire, and Advanced Distributor Products.

The primary authors were Ben Schoenbauer, Dave Bohac, and Patrick Huelman from the Center for Energy and Environment.

These authors would like to acknowledge the contributions and support from Jake McAlpine and Becky Olson for their project management, site recruitment, homeowner interfacing, cost analysis, and dedication to facilitating and championing this project; Pat Huelman from the University of Minnesota for his expertise and role as an advisor to the project; Alex Haynor, Corinne Wichser, Andrew Lutz, and Josh Novacheck from the Center for Energy and Environment for their work on field installations and data analysis; Anna Jursik and Helen Booth-Tobin from the Center for Energy and Environment for editing the report; Gary Nelson from the Energy Conservatory for donating space for the laboratory and his time as an advisor; Gary Klein from Affiliated International Management for his time and expertise; Louise Goldberg from the University of Minnesota's Department of Bioproducts and Biosystems Engineering for the BEopt modeling and analysis; and Tom Schirber from the University of Minnesota for coordinating and editing the report.

The authors would also like to thank the Sustainable Resources Center for their commitment to improving weatherization in Minnesota. Without their work staff, this project would not have been feasible.

Finally, the authors would like to thank the NorthernSTAR Research Team and BA. This report is the culmination of five years of work through BA. The support from both NorthernSTAR and BA made this project possible. 


\section{Executive Summary}

\section{Introduction}

Combined space and water heater (combi or combo) systems are defined by their dual functionality. Combi systems provide both space and water heating capabilities from a single heat source. This guideline focuses on the installation and operation of residential systems that have forced-air heating and domestic hot water (DHW) functionalities.

Combi systems are well suited for high-performance homes, where better insulation and tighter envelopes reduce space heating loads and make it possible for both space and domestic water heating loads to be provided by using a single heating plant.

In the past, mechanical contractors have often custom engineered and pieced together combi systems in the field. They focused on assembling functional systems with little attention to efficiency and optimization. However, as high-efficiency condensing water heaters and boilers gain a larger share of the residential market, there is greater potential to improve efficiency by providing both space heating and DHW loads by using a single heat source.

Based on previous Building America Program (BA) research conducted by the NorthernSTAR team, this measure guideline provides information to help installers, program managers, and builders capitalize on opportunities for increased heating, ventilating, and air-conditioning efficiency by using combi systems.

\section{Installation}

The best practice for combi system installation involves four steps. First, the home needs to be assessed to determine the heating and DHW needs. Second, the combi system components need to be selected. Third, the system can be installed. Fourth, the system needs to be optimized and set up to perform at the highest efficiency possible while still meeting the needs and comfort of the occupants.

\section{Performance and Cost}

Table A. Average Installed Performance of Combi Systems in 11 Homes

\begin{tabular}{|l|r|r|r|}
\hline \multirow{2}{*}{$\begin{array}{c}\text { Heating } \\
\text { Plant }\end{array}$} & \multicolumn{3}{|c|}{ Installed Efficiency } \\
\cline { 2 - 4 } & Annual & $\begin{array}{c}\text { Winter } \\
\text { Space Heat }\end{array}$ & $\begin{array}{c}\text { Summer } \\
\text { DHW }\end{array}$ \\
\hline StWH & $86 \%$ & $87 \%$ & $60 \%$ \\
TWH & $86 \%$ & $85 \%$ & $85 \%$ \\
HWH & $90 \%$ & $92 \%$ & $61 \%$ \\
Boiler & $84 \%$ & $86 \%$ & $76 \%$ \\
Existing & $71 \%$ & $72 \%$ & $47 \%$ \\
\hline
\end{tabular}

When properly installed and optimized, the high-efficiency combi systems that were analyzed for this measure guideline provided significant savings compared to the systems they replaced (a 
furnace with an annual fuel utilization efficiency [AFUE] of $80 \%$ furnace and a natural draft water heater with an energy factor $[\mathrm{EF}]$ of 0.58 ). Table A shows the average installed efficiencies measured in the field (Schoenbauer et al. 2014a). The table shows a significant increase in annual efficiencies for all combi systems (84\% to $90 \%)$ compared to the existing system $(71 \%)$. This increase in efficiency resulted in a $17 \%$ reduction in the energy consumption for homes that have a combi system based on a water heater.

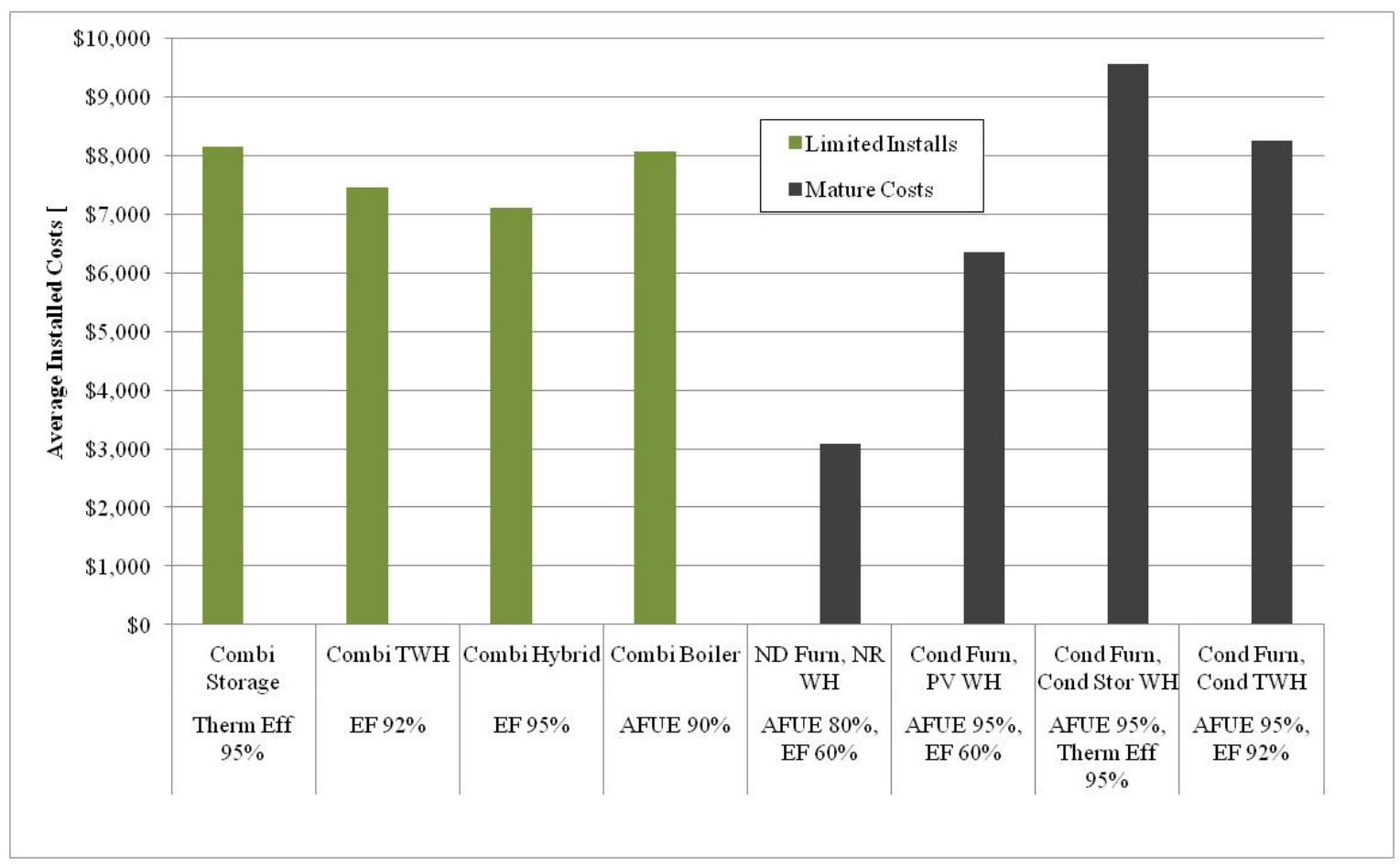

Figure A. Installation costs for residential heating, ventilating, and air-conditioning systems

Figure A compares the installed costs of combi systems to other systems types. The least expensive space and water heating option is a natural draft furnace and natural draft storage water heater ( $\mathrm{StWH})$. This inexpensive option is still common in some northern climate states. Typical costs for this base system are approximately $\$ 3,075$ ( $\$ 1,875$ for the furnace and $\$ 1,200$ for the water heater). A common system upgrade from this option is a condensing gas furnace (with an average AFUE of 94\%) and a power vent water heater (EF of 0.60). The power vent water heater offers only a minor update in EF rating (or no upgrade in some cases), and it is typically installed to resolve combustion safety concerns. On the open market, this system costs $\$ 6,350$ to install $(\$ 4,250$ for a condensing furnace and $\$ 2,100$ for the water heater), including local utility rebates. A homeowner seeking high-efficiency space and water heating could install a condensing furnace and either a condensing StWH (thermal efficiencies of 95\%) or a condensing tankless water heater (CTWH) (EF of 0.92 to $0.98 \%$ ). Open market installation costs for a condensing StWH were found to be $\$ 5,300$, and previous research (Schoenbauer et al. 2011 ) showed CTWHs with installed costs of $\$ 4,000$. Condensing combi systems were the lowest cost method of providing both condensing water heating and space heating. 


\section{Conclusions}

Combi systems have the potential to be an asset to builders, installers, and efficiency program managers. Combi systems are capable of matching the performance and efficiency of a separate condensing water heater and space conditioning system at a lower initial cost. Although in the past these systems required complex installations and on-site design, this is no longer the case. Current equipment can be installed and optimized following this guideline to achieve the energy savings and occupant comfort desired from a high-efficiency heating, ventilating, and airconditioning system. 


\section{Problem Statement}

\subsection{Introduction}

Combined space and water heater (combi) systems are defined by their dual functionality. Combi systems provide both space heating and water heating capabilities from a single heat source. This guideline focuses on the installation and operation of residential systems that have forced-air heating and domestic hot water (DHW) functionalities. Past NorthernSTAR research used a combi system to replace a natural gas forced-air distribution system furnace and tank water heater (Schoenbauer et al. 2012; Schoenbauer et al. 2014b). The combi systems consisted of a water heater or boiler heating plant teamed with a hydronic air handling unit (AHU) that included an AHU, water coil, and water pump to circulate water between the heating plant and coil. The combi water heater or boiler had a separate circuit for DHW.

Past projects focused on laboratory testing, field characterization, and control optimization of combi systems. Laboratory testing was done to fully characterize and test combi system components. Then field-testing was completed to characterize the installed performance of the combi systems. Next, control methodologies were analyzed to understand the potential of controls to simplify the installation and design and improve system efficiency and occupant comfort. This past work was relied upon on to create this measure guideline.

\subsection{Background}

Combi systems are well suited for installations in high-performance homes, where better insulation and tighter envelopes reduce space heating loads. Decreased space heating loads make it possible for both space and domestic water heating loads to be provided by using a single heating plant. Additionally, tighter construction often does not allow naturally vented appliances to properly vent combustion products. High-efficiency combi systems use direct vents that eliminate combustion safety concerns.

In the past, mechanical contractors have often custom engineered and pieced together combi systems in the field. They focused on assembling functional systems and paid little attention to efficiency and optimization. As high-efficiency condensing water heaters and boilers gain a larger share of the residential market, there is greater potential to improve the efficiency of providing both space heating and DHW loads by using a single heat source.

The concept of using a single heating plant to supply both space and water heating has been around for many years. Bohac et al (1991) installed and monitored combi systems in small commercial and multifamily buildings in 1989 . These combi systems used a natural draft storage water heater as the heating plant. They had annual fuel utilization efficiency (AFUE) ratings of at least $78 \%$, and they replaced natural draft water heaters with efficiencies of approximately $50 \%$ and furnaces with AFUEs of approximately $60 \%$. The 1.5 years of monitored operation demonstrated that these systems could be reliably installed and perform without failure while saving energy. The study found an average natural gas savings of $24 \%$.

Twenty years ago, a combi system using a non-condensing water heater could provide energy savings when they replaced older, low-efficiency furnaces and water heaters. Today, in many 
parts of the country, furnaces with efficiency ratings of $90 \%$ or higher are more standard. Laboratory testing (Thomas 2011) demonstrated that when combi systems are used to replace mechanical equipment in modern homes, they must use condensing heating plants to achieve similar or improved energy performance levels.

For combi systems to become more widely used, field research and demonstration projects were needed to address several outstanding questions such as What is the actual installed energy savings of a properly configured combi system with a condensing heating plant? What are the installation costs and paybacks of these systems? Can contractor familiarity and experience with combi systems reduce installation prices?

Combi systems using high-efficiency heating plants are relatively new on the market, and laboratory tests and field installations have identified potential problems. Laboratory tests by Brookhaven National Laboratory (Butcher 2011) showed that the manufacturer-specified plumbing configuration with a primary and secondary loop made it difficult to achieve the highefficiency potential of condensing combi boilers. A field installation by the New York State Energy Research and Development Authority (Rudd 2010) examined durability issues for systems using tankless water heaters (TWHs). The study assessed problems with hard water, scaling, and short-cycling. The combi system installed had buildup on the inlet water filter of the TWH. This buildup eventually prevented the TWH from activating. As a solution to this issue, the researchers installed an industrial strainer on the inlet water line that prevented water heater failure and reduced the maintenance interval to an annual filtering.

In 2009, the BA team Consortium for Advanced Residential Buildings analyzed the performance of six condensing boilers in existing homes (Arena 2011). The analysis discovered that they were all operating well below their rated efficiencies. In space heating mode, the frequency of condensing operation was between $14 \%$ and $69 \%$. In domestic water heating mode, the frequency of condensing operation was between $18 \%$ and $65 \%$. Three major factors contributed to the lack of condensing at these six sites: set point temperature that was greater than $180^{\circ} \mathrm{F}$, high secondary or distribution system flow rates that produced a low temperature drop across the radiation system, and a primary/secondary plumbing loop configuration that increased return water temperatures.

NorthernSTAR (Schoenbauer et al. 2014a) implemented combi systems in 200 homes and conducted a detailed monitoring study of 20 homes. This project collected valuable information on combi system performance and occupant comfort and showed that properly configured combi systems typically operate at an annual efficiency between $85 \%$ and $92 \%$, which results in $19 \%$ average savings compared to a natural draft water heater and non-condensing furnace. Careful monitoring also highlighted potential areas for improvement. These areas were analyzed as a part of this project.

\subsection{Relevance to Building America's Goals}

Combi systems have the potential to significantly reduce home energy use. A properly installed combi system can provide approximately $20 \%$ natural gas savings compared to an $80 \%$ AFUE 
furnace and a $60 \%{ }^{1}$ energy factor $(\mathrm{EF})$ water heater. Additionally, replacing a natural draft water heater with a direct vent heating plant allows the home to be more airtight without causing combustion safety issues, and it eliminates air infiltration through the combustion makeup air duct, further improving the energy performance of a home.

Combi systems are a feasible option for a high fraction of houses in most climate regions. In colder climates, the application may not have sufficient heat output for larger homes with very poorly insulated and leaky envelopes. Some currently available equipment can meet space heating design loads up to $70,000 \mathrm{Btu} / \mathrm{h}$ while still operating in the condensing mode. Higher capacity hydronic coils would allow current heating plans to meet even higher space heating loads.

Combi systems are capable of providing both high-efficiency space and water heating at a lower cost than two separate high-efficiency appliances. Previously, each installation required customized contractor designs, equipment selection, and commissioning to ensure the proper installation, sizing, and operation needed to achieve efficient performance. The installation and optimization process used by NorthernSTAR for the previous field project was summarized in the final report. Additional work led to this full measure guideline for the design, installation, optimization, and verification of combi system performance (Schoenbauer et al. 2012, Schoenbauer et al. 2014a).

In addition to improving the efficiency and energy savings of combi systems, previous projects addressed the installation and design difficulties of combi systems. Improved control can reduce the necessity of having a system designed and manually adjusted to narrowly defined, optimized parameters. Combi system efficiency is largely a factor of the water temperature returning to the heating plant from the AHU and burner cycling characteristics. Lower return temperatures and longer cycles produce higher system efficiency. All current AHUs have a constant airflow rate and constant water circulation flow rate for the heating mode. To achieve the best performance, these flow rates must be adjusted to meet the house design heating load while minimizing the return water temperature. Variable air and water flow rate control would allow for a single AHU to provide more efficient performance over a wider range of heating loads and should eliminate time-consuming, manual adjustments to the water flow rate. The controls improve efficiency by allowing the system to operate at a lower average return water temperature and for longer cycles.

\subsection{Cost-Effectiveness}

The installation cost of a high-efficiency combi system may be lower than the cost of separately installing a furnace and water heater with similar efficiencies. In a retrofit application, a homeowner can expect to pay approximately $\$ 4,250$ for a high-efficiency $(90 \%-98 \%$ AFUE) furnace and $\$ 5,300$ for a high-efficiency $(0.80 \mathrm{EF}-0.95 \mathrm{EF})$ storage water heater. In the Minneapolis area, contractors that have limited combi system experience currently bid a highefficiency system for $\$ 8,200$ on average with a typical range from $\$ 6,500$ to $\$ 10,000$. Combination systems are more cost effective than separate condensing space conditioning and water heating systems.

\footnotetext{
${ }^{1}$ For a gas-fired water heater with a rated storage volume of 40 gal
} 


\subsection{Trade-Offs and Other Benefits}

Combi systems have several secondary benefits. By replacing a separate furnace and water heater with a single boiler or water heater, combi systems reduce the number of gas lines and exhaust vents from two to one, which often reduces the equipment footprint. In new construction, reducing the mechanical system footprint can be a significant benefit. A reduced footprint allows for more flexibility in installation and more usable space. A reduced footprint is often less valuable in retrofit applications, but it can provide additional usable space in a finished basement or work room. A single high-efficiency burner also has combustion safety and venting benefits; high-efficiency combi heating plants have power-vent or sealed combustion burners that eliminate combustion spillage concerns for tight houses.

The largest trade-off with combi systems is the installation and optimization of the system. Combi systems do not require any new or unique skills, but they do require contractors to acquire training and experience to learn a new procedure for installation to effectively integrate the combi systems. 


\section{Implementation Details}

\subsection{Installation}

The best practice for combi system installation includes four steps. First, the home should be assessed to determine the heating and DHW needs. Second, the combi system components need to be selected. Third, the system can be installed. Fourth, the system should be optimized and set up to perform at the highest efficiency possible while still meeting the needs and comfort of the occupants.

\subsubsection{House Assessment}

Quality space heating and DHW installation should include an assessment of the space heating and DHW loads for current and future occupancy. The assessment should also include a space heating design load calculation, a characterization of the DHW load, and a water quality assessment.

There are two primary methods for sizing the heating load of an existing home. Detailed information can be taken from the home's thermal properties to develop a heat-loss model. The most common method for estimating the heating load of a home in this manner is by using a Manual J calculation. Many software programs can be used to collect household characteristics and calculate a Manual J heating load. The National Energy Audit Tool (NEAT) audit tool used by many weatherization agencies in the United States was used to estimate heating load in this study. To estimate the design load, the calculations must estimate the heat transfer into and around a residential building, including the heat conduction and airflow through detailed and complex building assemblies. Inconsistencies in construction, limited access, and incomplete information can make it difficult to collect data about the building's characteristics. In addition, occupant behavior, such as adjusting the thermostat or changing occupancy, can significantly change the load of a building. Because of this, a direct calculation of the heating load is more accurate and desirable for specific occupants. Past utility data and outdoor weather data can be used to determine the energy used in a home for space heating. This data can also be used to determine the design heating conditions.

Figure 1 shows the comparison of the calculated and modeled heating load for several Minnesota homes that were included in this project. The NEAT modeled load was an average of 10,000 $\mathrm{Btu} / \mathrm{h}$ higher than the measured design heating loads. Detailed data was collected on the energy consumption and output of the space conditioning systems in each home. The daily data was analyzed with the outdoor air temperature to calculate the design day heating loads at each site. The differences in the two methods of calculation were likely due to the methodology of the Manual J calculation, which was designed for sizing heating and cooling equipment. For an installer, undersizing equipment is unacceptable because it will result in customer dissatisfaction and callbacks. For contractors, although oversizing may lead to degraded performance, the building will still be heated and/or cooled to acceptable levels. Therefore, the calculation methods and data entered into the Manual J calculation are typically more conservative and overpredict the load. In addition, Manual $\mathrm{J}$ does not account for specific occupant behavior or internal gains, and it makes generic assumptions. Occupants, lights, and appliances generate heat, and these internal gains reduce the home space heating load and differ greatly depending on many variables specific to each home and its occupants. The monitored data from this study 
directly accounted for these internal gains and did not add any conservative estimates. This led to the lower design loads.

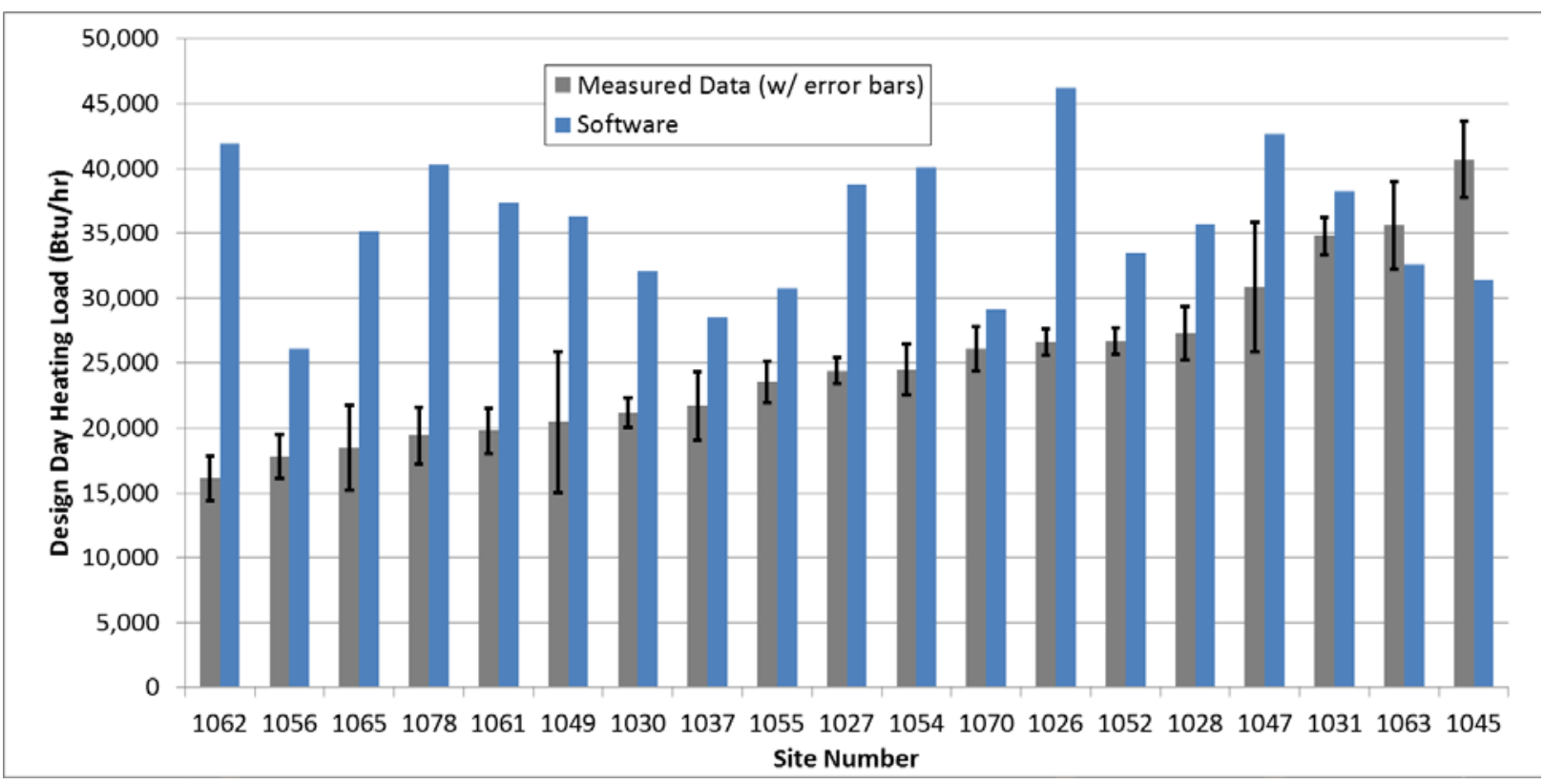

Figure 1. Sample heating-load calculations for Minnesota homes

The household assessment should also include a characterization of the hot water load. Hot water systems are sized based on expected peak hot water load. In a home, this is based on the number of simultaneous showers that could occur, which is determined by the number of occupants expected and the number of shower or tub fixtures in the home, as well as information on minimum mains water temperature delivered to the home from the municipality.

The water quality of the home should also be assessed prior to installation. Water heater and boiler warranties often require specific water quality levels. A water softener or filter should be used in areas that have hard water to improve water quality. In addition, these systems require maintenance to achieve the necessary water quality. A community, city, or water utility report typically provides the information necessary to ensure that either the warranty conditions are met or if a softener is needed. Each heating plant has their own requirements for water quality, and the operation manual should be consulted for specific requirements. In general, most water heaters have a water hardness maximum between 6 and 10 grains per gallon, and at least one water heater is able to operate at up to 15 grains per gallon.

\subsubsection{Equipment Selection}

The focus of this measure guideline is on high-efficiency, residential, natural gas, forced-air combined space and water heating systems. These systems have two major components: the heating plant and the hydronic AHU. The heating plant is either a condensing water heater or a condensing boiler that supplies hot water to the hydronic coil in an AHU for space heating and either directly to fixtures or through a heat exchanger for DHW. There are several options for both the heating plant and the hydronic AHU. Table 1 lists a sample of the heating plants that 
can be used for combi systems. The systems listed were all considered and selected for installation in a least two sites in a Minnesota pilot project (Schoenbauer et al. 2014a).

Condensing water heaters have three main types of design: storage, tankless, or a hybrid of two designs. Condensing storage water heaters (CStWHs) typically have a storage capacity of 34 gal or greater with burner input capacities of $100,000 \mathrm{Btu} / \mathrm{h}$ or greater. These water heaters use a large volume of storage with a moderate burner to provide the capacity necessary to meet the combined load of a home. These systems are typically controlled by measuring the stored water temperature and activating the burner when the temperature drops below a specific level. That temperature drop (or dead band) can be adjusted, but for condensing units it is typically between $3^{\circ} \mathrm{F}$ and $7^{\circ} \mathrm{F}$. A $7^{\circ} \mathrm{F}$ dead band is much smaller than the dead band used by most non-condensing water heaters (typically around $20^{\circ} \mathrm{F}$ ). A smaller dead band results in less variance in outlet water temperature, which may increase homeowner comfort and makes system performance more uniform.

Condensing tankless water heaters (CTWHs) store little or no hot water. Tankless units rely on large modulating burners (often up to $200,000 \mathrm{Btu} / \mathrm{h}$ ) to meet the hot water loads in real time. When a hot water event is registered by the water heater, the burner activates and heats the water as needed. The installation of a retrofit combi system requires modifying the gas supply lines in the home. Combining two gas burners into a single combi system requires eliminating some gas lines. In some cases, modification may be necessary to increase gas supply capacity to the location of the combi system.

Hybrid water heaters (HWH) are a combination of the CStWH and the CTWH. These condensing water heaters typically have modulating burners with firing rates between 100,000 $\mathrm{Btu} / \mathrm{h}$ and 200,000 Btu/h and some storage capacity. The storage capacity allows for a slightly smaller burner firing rate while also providing some stored hot water to offset some of the hot delivery changes with TWHs. The small storage capacity allows the HWH to deliver hot water the instant a draw is activated without a delay as the burner ramps up to temperature (common for TWHs). The storage capacity also eliminates the minimum flow rate required to activate a TWH.

In addition to water heaters, condensing boilers can be used for the combi system heating plant. Although boilers are traditionally used with hydronic distribution, they can be successfully paired with hydronic AHUs for forced-air heating. Condensing combi boilers are typically wall hung and contain plumbing fittings for both a space heating loop and a DHW loop. All combi boilers contain an internal circulation pump to control the flow of water through the boiler. Most combi boilers use one of two approaches for DHW. The first is used by low-mass boilers that do not have storage tanks. These boilers use a water-to-water heater exchanger (typically a flat plat heat exchanger) to transfer heat from the internal loop to the DHW plumbing. When a hot water draw is initiated, the boiler senses the flow and starts the burner, which provides hot water to the heat exchanger. The heat exchanger transfers heat into the DHW system, and hot water flows to the fixture. The second DHW design for condensing combi boilers is to use an internal storage tank. This tank functions similarly to an indirect tank. The storage tank is kept hot and connected to the DHW plumbing. The storage tank provides hot water to the fixtures, and when the tank temperature drops enough, the boiler fires and reheats the storage tank through a water-to-water heat exchanger in the storage tank. Most boilers allow the user to set the hot water temperature, 
which controls the water storage temperature and the outlet temperature. One manufacturer's design does not allow the user to change the water temperature set point inside the boiler. These boilers circulate and store water inside the boiler at a set temperature. The user can control the DHW outlet temperature with a mixing valve internal to the boiler system.

Table 1. Sample Heating Plants That Can Be Used for Combi Systems

\begin{tabular}{|c|c|c|c|c|c|}
\hline \multicolumn{2}{|c|}{ Equipment Type } & Manufacturer & Model & $\begin{array}{c}\text { Input } \\
\text { (kBtu/h) }\end{array}$ & $\begin{array}{c}\text { Storage } \\
\text { (gal) }\end{array}$ \\
\hline Condensing boiler & Low-mass & Rinnai & E75C & $17-75$ & 0 \\
\hline Condensing boiler & Storage & Rinnai & Q175C & $35-175$ & 7 \\
\hline Condensing boiler & Low-mass & Navien & $\begin{array}{l}\text { Combi } \\
\text { Boiler }\end{array}$ & $20-175$ & 0 \\
\hline Condensing boiler & Storage & Triangle Tube & Prestige & $30-110$ & 12 \\
\hline Condensing water heater & Tankless & Rinnai & 98Lsi & $9.5-199$ & 0 \\
\hline Condensing water heater & Hybrid & Grand Hall & Eternal & $31-199$ & 2 \\
\hline Condensing water heater & Storage & A.O. Smith & Vertex & 100 & 50 \\
\hline Condensing water heater & Storage & $\begin{array}{l}\text { Heat Transfer } \\
\text { Products }\end{array}$ & Phoenix & $35-100$ & 55 \\
\hline Condensing water heater & Storage & American & Polaris & 100 & 34 \\
\hline
\end{tabular}

Another major system component of the combi system is the hydronic AHU. The hydronic AHU consists of three main components: a blower fan, a hydronic air coil, and a water pump. Although designs differ, fan size, pump size, and coil heat all impact transfer effectiveness. Table 2 lists a sample of the hydronic AHUs available. This list is not comprehensive; many manufactures and model options are available that are not included here.

Table 2. Sample Hydronic AHUs

\begin{tabular}{|c|c|c|}
\hline Equipment Type & Manufacturer & Model \\
\hline Hydronic AHU & Rinnai & $37 \mathrm{AHB} 060$ \\
\hline Hydronic AHU & Rinnai & 37AHB075 \\
\hline Hydronic AHU & $\begin{array}{c}\text { Advanced } \\
\text { Distribution } \\
\text { Products }\end{array}$ & BVR00031s4p3 \\
\hline Hydronic AHU & NuAire & en7030i \\
\hline Hydronic AHU & Enerzone & xah70vs-x13-pt-4row \\
\hline Hydronic AHU & First Company & 8VMR \\
\hline $\begin{array}{c}\text { Non-potable hydronic } \\
\text { AHU }\end{array}$ & Lennox & cbwmv-36c-090-1 \\
\hline
\end{tabular}

Hydronic AHUs may or may not be rated for potable use. The systems rated for potable use are used in open-loop combi systems where the water in the space heating and DHW loops are able to mix with each other (Figure 2). In these systems, water may circulate through the AHU, return to the water heater, and then be used for DHW. These potable systems can be designed with heating plants with dedicated space heating water taps (Figure 2a) or with only two water taps (Figure 2b). AHUs that are not rated for potable use can be used in a closed-loop configuration that has a closed space heating loop. Water that circulates through the AHU is isolated from the 
potable DHW system, and there is no mixing. The major difference between AHUs rated for potable use and those that are not are the controls. The potable systems have timers that force water to be circulated through the AHU during stagnant periods and prevents the water from being stagnant for long periods when heating is not required.

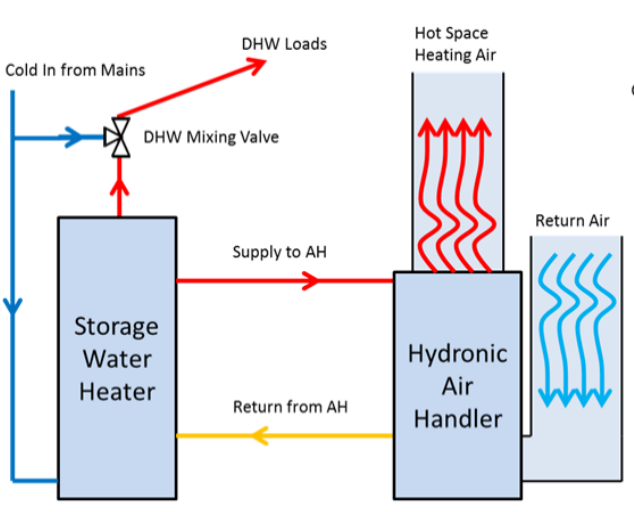

a)

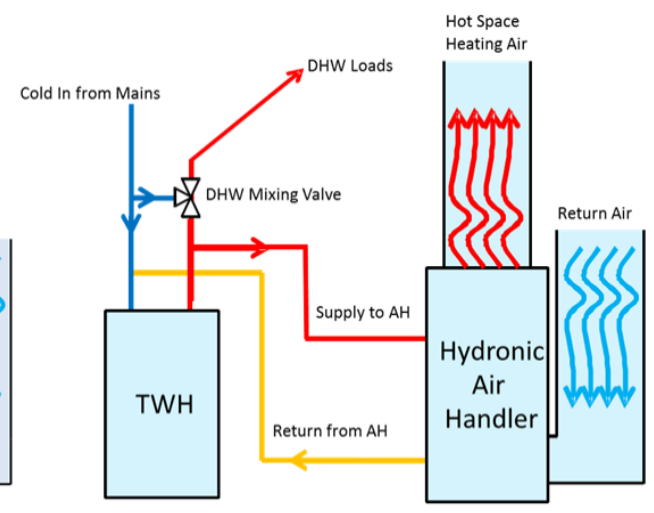

b)

Figure 2. Forced-air combination systems using open loops and potable AHUs

Another important design characteristic of hydronic AHUs is integration with other forced-air components. Some AHU designs contain air-conditioning coils within the AHU, whereas others are designed to fit under a traditional air-conditioning coil. It is important to select an AHU that will integrate with other components and the distribution system.

When selecting a heating plant and hydronic AHU, it is important to weigh the drawbacks and benefits of each component and the combined system. The selection should be based both on the initial installation considerations and on continuous operational and performance considerations.

Several factors differentiate the three heating plant choices. Table 3 summarizes the benefits and drawbacks of each heating plant type. The storage for the StWHs and HWHs allows those water heaters to immediately generate hot water for DHW or space heating uses. Because the TWHs do not store hot water, there is a time delay between the start of hot water use and hot water production while the burner and heat exchanger come up to temperature. TWHs and HWHs can be wall mounted and have a smaller footprint than conventional water heaters and condensing StWHs. Therefore, a combi system using a TWH or HWH reduces the mechanical footprint in some installations. This may be ideal for situations with limited space.

All water heaters are impacted by hard water, and water hardness must be considered in the system design. In condensing StWHs, the stainless steel tank helps prevent damage from hard water. TWHs require heat exchangers with large surface areas to heat water on demand. The surface area can be increased by reducing the size of the water pipes and increasing the number of paths in the heat exchanger. However, these smaller passageways are more susceptible to damage and blockage from scaling buildup. Another temperature-control method for TWHs is to overheat the water in the heat exchanger and mix in cold water to meet the desired set point. These smaller passageways and increased temperatures increase the risk of hard water fouling for TWHs, and for this reason TWH manufacturers require either good water quality or annual flushing and maintenance as part of the warranty. 
The relative simplicity of the design of an StWH and the ease in which it is installed benefit long-term maintenance and durability and also reduce the installation and optimization time. StWHs have simple designs and include four water taps, making the installation simple and straightforward. This differentiates StWHs because the complex design of many TWHs and HWHs make maintenance difficult, and specialized training is often necessary to troubleshoot and repair these units. Although these drawbacks may diminish as these units become more common, they need to be considered at this time.

Table 3. Benefits and Drawbacks of Heating Plant Selection

\begin{tabular}{|c|c|c|c|c|c|}
\hline Feature & SWH & TWH & $\begin{array}{c}\text { Hybrid } \\
\text { Water } \\
\text { Heater }\end{array}$ & $\begin{array}{c}\text { Low-Mass } \\
\text { Boiler }\end{array}$ & $\begin{array}{c}\text { Boiler w/ } \\
\text { Storage }\end{array}$ \\
\hline Hot water delay & Benefit & Drawback & Benefit & Drawback & Benefit \\
\hline Unit size (footprint) & Drawback & Benefit & Benefit & Benefit & Depends $^{\mathrm{a}}$ \\
\hline Operation w/hard water & Benefit & Drawback & Drawback & Benefit & Benefit \\
\hline Simplicity of design & Benefit & Drawback & Drawback & Drawback & Drawback \\
\hline Ease of installation & Benefit & Drawback & Drawback & Drawback & Benefit \\
\hline Install cost & Benefit & Benefit & Benefit & Drawback & Drawback \\
\hline
\end{tabular}

${ }^{a}$ All of the boilers studied were wall hung, but some were large enough that installation was cumbersome.

For this project, the AHU selection was based on the required space heating load of the home. The capacity range of a properly installed AHU for a high-efficiency combi system was found to be at least 1.5 times greater than the home space heating demand plus a safety factor. Oversizing the AHU allows for flexibility in delivery capacity and proper system optimization for highefficiency operation (see Section 2.1.4). Although laboratory testing showed that optimized performance could occur with an AHU with 1.5 times the design capacity, a minimum oversize factor of 1.75 was used. The extra capacity of the AHU allowed for greater flexibility and increased the output range for which the system could be optimized.

\subsubsection{Installation}
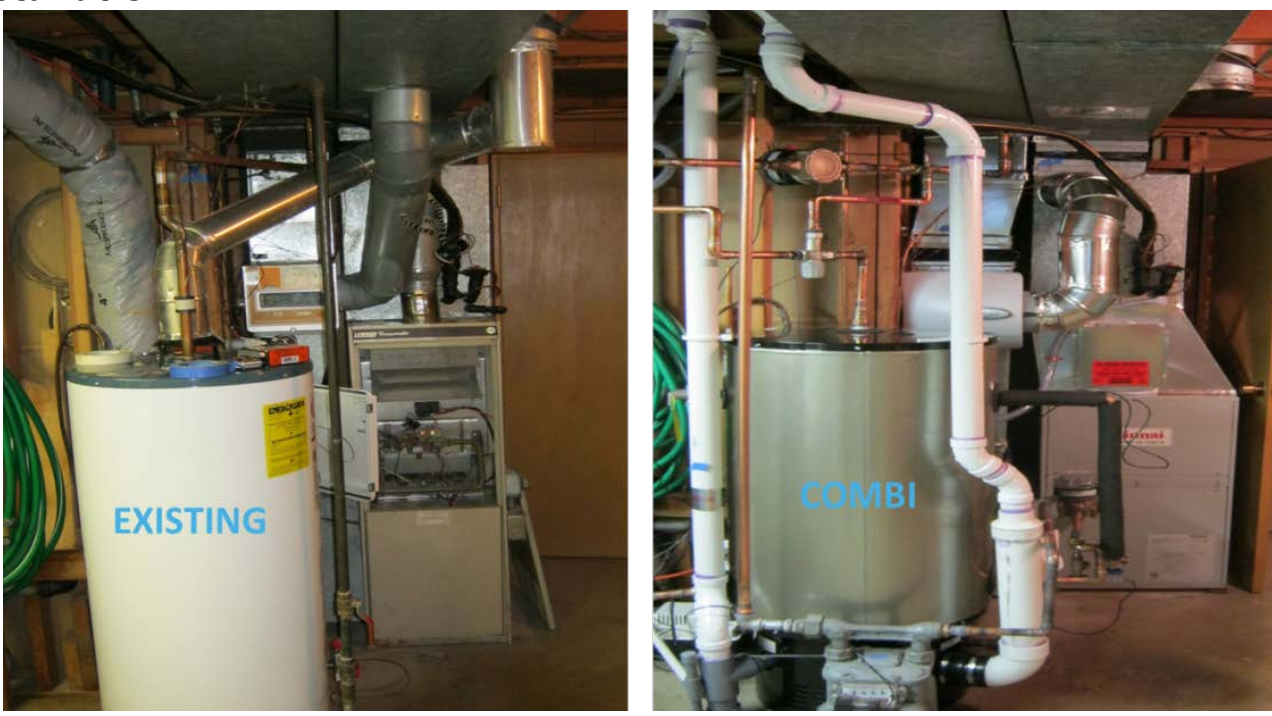

Figure 3. Comparison before and after installation 


\subsubsection{Codes and Regulations}

Some code officials may not have seen a combi system and may have concerns or questions about specific issues. For example, one issue with combi systems is running potable water through the hydronic AHU and pump, which need to be rated for potable water. There also needs to be a method to prevent stagnant water in that loop. In most systems, that is accomplished by using a control on the circulation pump that runs the pump intermittently to flush the loop. Code officials are likely to have other questions about the systems. To help answer these questions, this project set up a demonstration system in the lab and invited code officials to see the demonstration, ask questions, and share their concerns. This was done well before the first installations to obtain the code officials' buy-ins before the contractors started getting permits.

\subsubsection{Sizing}

Combi systems have a lot of flexibility in the delivered heat output, and system components are capable of meeting the high residential heating capacities as well as much smaller loads than most commonly available residential heating equipment. The range of the combi system's delivered heating capacity increases the flexibility of the system and allows for a much smaller safety factor. Traditional forced-air equipment comes with either a fixed output or, for modulating capacity systems, a fixed maximum output. These fixed rates often come in a few discrete sizes: $60,000 \mathrm{Btu} / \mathrm{h}, 80,000 \mathrm{Btu} / \mathrm{h}$, or $100,000 \mathrm{Btu} / \mathrm{h}$. The sizing process typically assumes a safety factor that is from $10 \%$ to $20 \%$ above the measured load. The discrete sizing options available typically increase the frequency and ratio (system output to design output) because the larger capacity furnace is always selected. The flexibility of the combi system provides contractors comfort in knowing that if the delivered capacity is not sufficient in meeting the load, a simple change in set point can increase the capacity without requiring a new installation or significant retrofit.

A sizing application guideline has been developed for combi systems based on the calculated design heating and DHW loads of the home. The sizing guideline assumes that the combi load is able to deliver the peak load, with peak load defined as all possible showers flowing at the minimum mains water temperature while the space heating system is active.

Figure 4 shows sizing guidelines for high-efficiency combi systems by heating plant type. The guidelines were developed based on equipment specifications and laboratory testing. Each line in the figure represents a single heating plant model. For a home that has an expected DHW load of two simultaneous showers, the figure shows the relationship between the home's design heating load (x-axis) and the minimum burner input rate (y-axis) to meet the load. For example, a home with a design heating load of $20,000 \mathrm{Btu} / \mathrm{h}$ would require a TWH with an input capacity of at least $165,000 \mathrm{Btu} / \mathrm{h}$ to meet the peak load of this home. A water heater with storage capacity requires a smaller input capacity because of the capacity of the storage. A 60-gal storage water heater requires an input of only $100,000 \mathrm{Btu} / \mathrm{h}$ for the same home. Some of the heating plants have a DHW priority that locks out the space heating when there is a DHW draw. In this type of case, the burner capacity for a combi system needs to meet only the peak shower draw.

This project used a conservative thermal efficiency of $85 \%$ to determine the output capacity of the heating plant burner. The output capacity of the hot water storage volume was computed from the rate of energy output for a $30^{\circ} \mathrm{F}$ temperature drop in the storage volume for a typical shower draw of 20 minutes. It was also assumed that the inlet water temperature was $37^{\circ} \mathrm{F}$ and 
the mixed shower temperature was $105^{\circ} \mathrm{F}$. The storage capacity calculations were verified with measured data in the laboratory for simulated shower events.

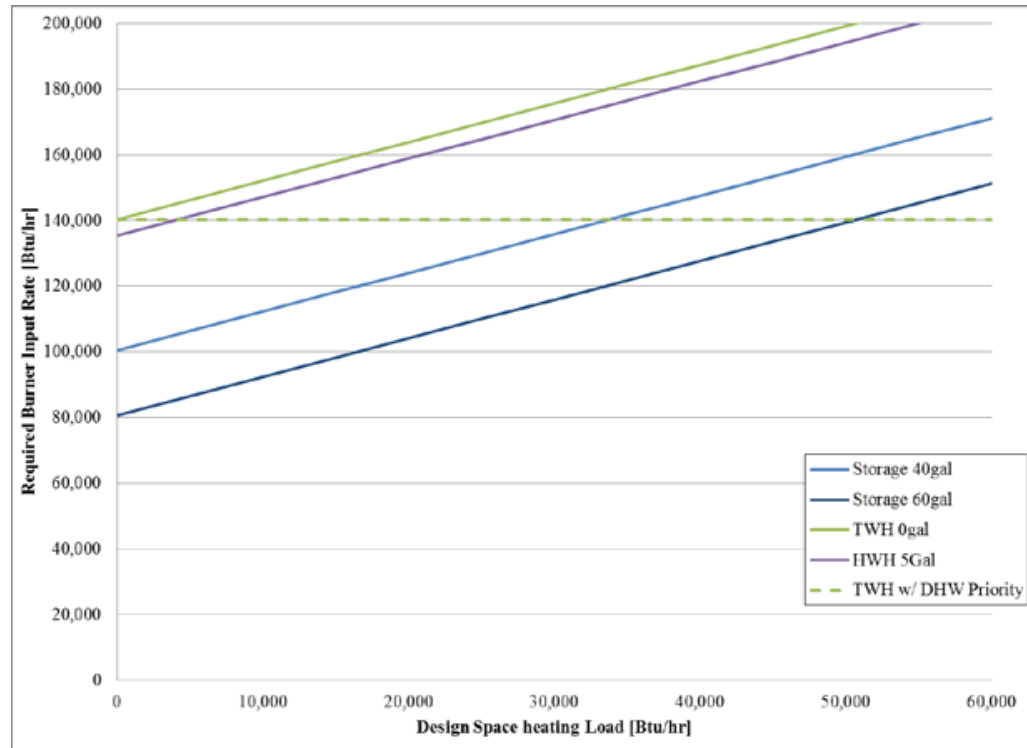

Figure 4. Example of combi system sizing for a two-bathroom home in a cold climate

\subsubsection{Components}

Upgrading to a high-efficiency water heater requires some changes in the installation whether the system is being used as a combi system or as a water heater alone. These changes may include modifying the gas supply lines, installing additional electrical service, adding a condensate line or pump, and installing a new intake air and combustion vent exhaust system. These changes are described in system installation manuals and should be followed.

These installations required removing the natural draft furnace and water heater that had a single wall or B-vent connected to a common vent or chimney Figure 5a) and replacing them with sidevented power and direct vent systems (Figure $5 \mathrm{~b}$ ). These units all produced condensate. When this occurs, the condensate can run to the floor drain if one is nearby. Otherwise, a condensate pump would need to be installed to take away the condensate (Figure 6). Additionally, some condensing systems require a condensate neutralizer to be installed to safely use the water drainage system.

Both a DHW mixing valve and AHU circulation flow control were added to all combi systems included in developing this measure guideline. The DHW mixing valve (Figure 7) was added near the outlet of the water heater. This mixing valve allowed the hot water from the water heater to be tempered with cold water and provided greater flexibility for space heating optimization. This allowed an increase in water heater supply water temperatures without the risk of scalding users. A balancing valve was installed on the return water pipe between the AHU and the water heater, and this valve was used to manually adjust the water flow rate during optimization (Figure 8). Ideally this valve would be replaced by a modulating AHU circulation pump, but these pumps were not available for the units that were being tested. 


\section{u.s. DEPARTMENT OF | Energy Efficiency \& \\ Renewable Energy}

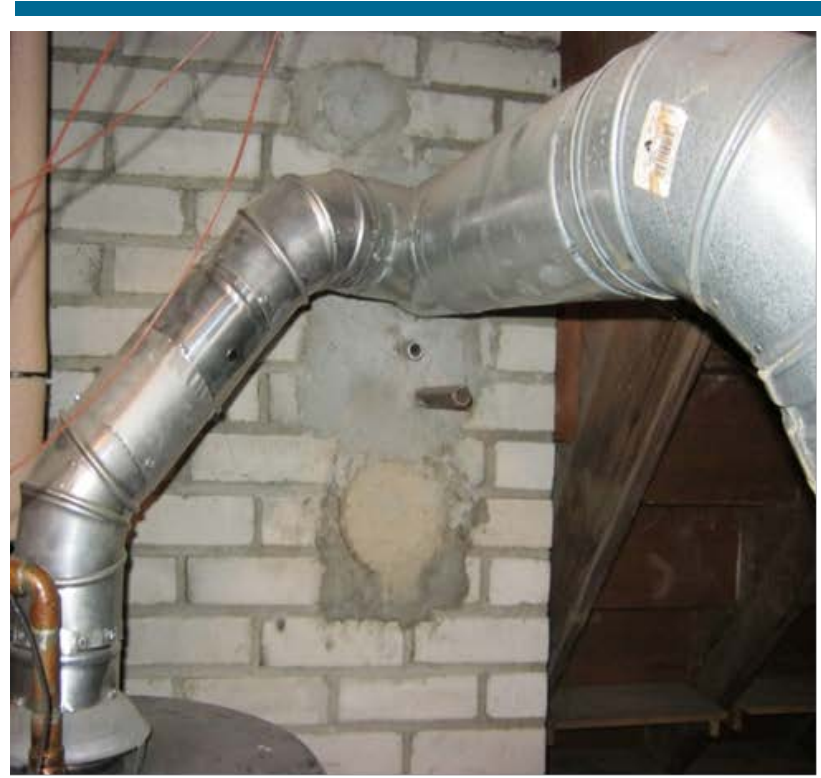

a) B-vent

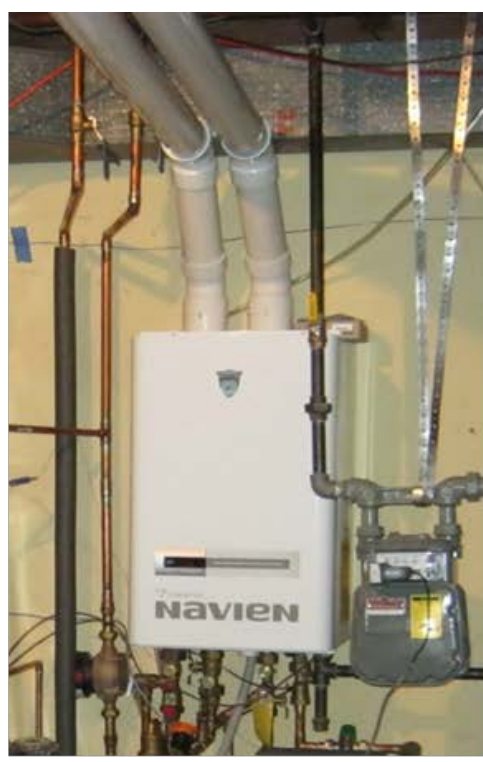

b) 2 pipe vent system

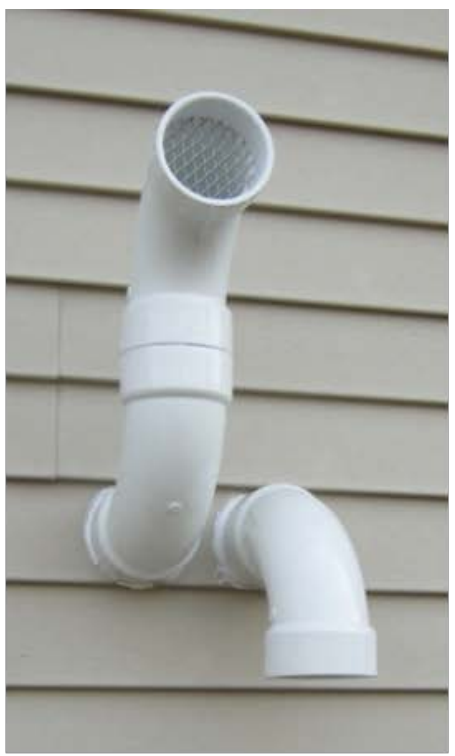

c) 2 pipe termination

Figure 5. Single-wall water heater and furnace vents replaced with direct vent system 


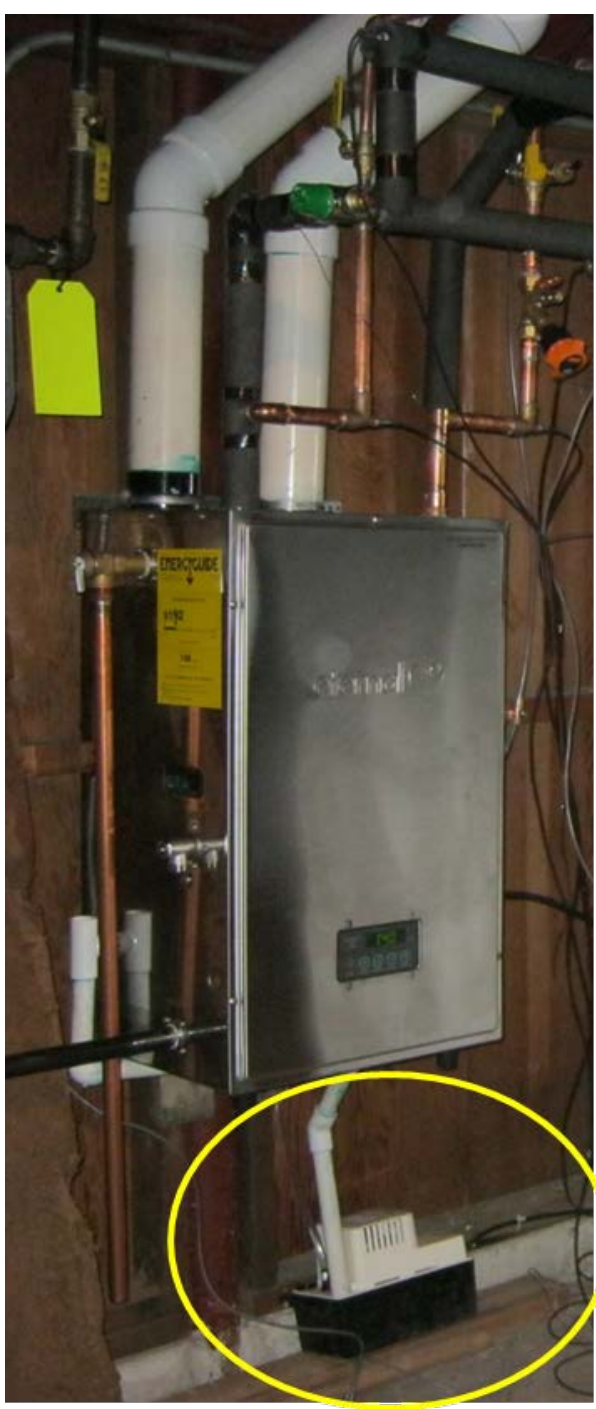

Figure 6. Condensate pump

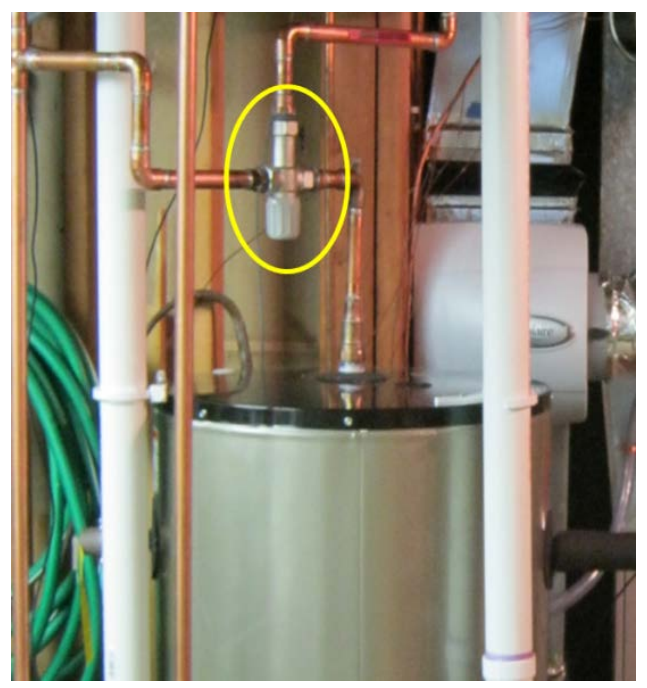

Figure 7. DHW mixing valve 


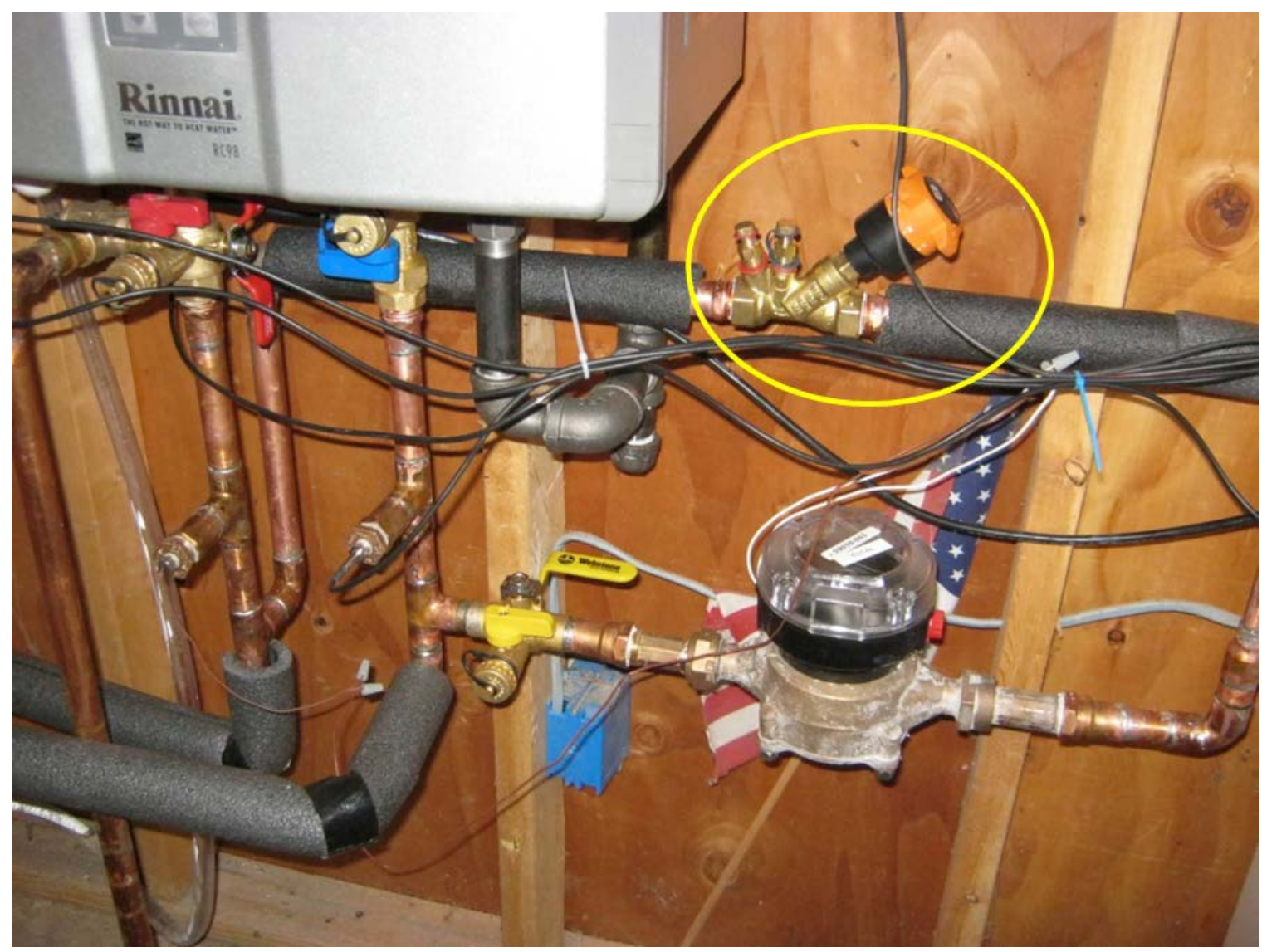

Figure 8. Water circulation balancing valve

\subsubsection{Optimization}

After combi systems are selected, properly sized, and installed, they need to be optimized to maximize efficiency and occupant satisfaction. Extensive laboratory testing was conducted to determine the optimized operating performance of combi systems (Schoenbauer et al. 2012). That knowledge was used to properly optimize the combi systems examined for this project. The water heaters were set up for optimal DHW operation by the manufacturer, and the space heating optimization was prioritized over DHW optimization for the combi systems. Systems were optimized by adjusting the temperature of the water heater set point, the water circulation rate through the AHU, and the airflow rate of the AHU. The water temperature returning from the AHU to the water heater is the most important parameter in maximizing space heating efficiency. Figure 9 shows the relationship between the return water temperature and system efficiency. A condensing boiler has increased efficiency because of water vapor condensing out of the fuel gases. The energy released during this phases change is transferred through a heating surface into the boiler water. The lower the temperatures of the heat transfer surface, the more energy that can be captured from the fuel gas and the higher the efficiency.

Each curve represents the performance of a specific heating plant under a single set of operating conditions. Although the curves should not be used to determine the exact performance of all systems, they are presented here to show the general trend in efficiency with return water 
temperature. In general, it was found that lower return water temperatures improved the space heating efficiency of the systems. The efficiency of most systems started to reach diminishing improvements of efficiency for return temperatures below $100^{\circ} \mathrm{F}$ to $105^{\circ} \mathrm{F}$, with some units resulting in large reductions in efficiency at water temperatures greater than $120^{\circ} \mathrm{F}$. At these nonoptimized conditions, the systems operated near $80 \%$ efficiency, which was the rated efficiency of the furnaces they were replacing. A maximum return water temperature of $105^{\circ} \mathrm{F}$ was selected to provide a good trade-off among higher efficiency, reasonable hydronic AHU coil size, and cost.

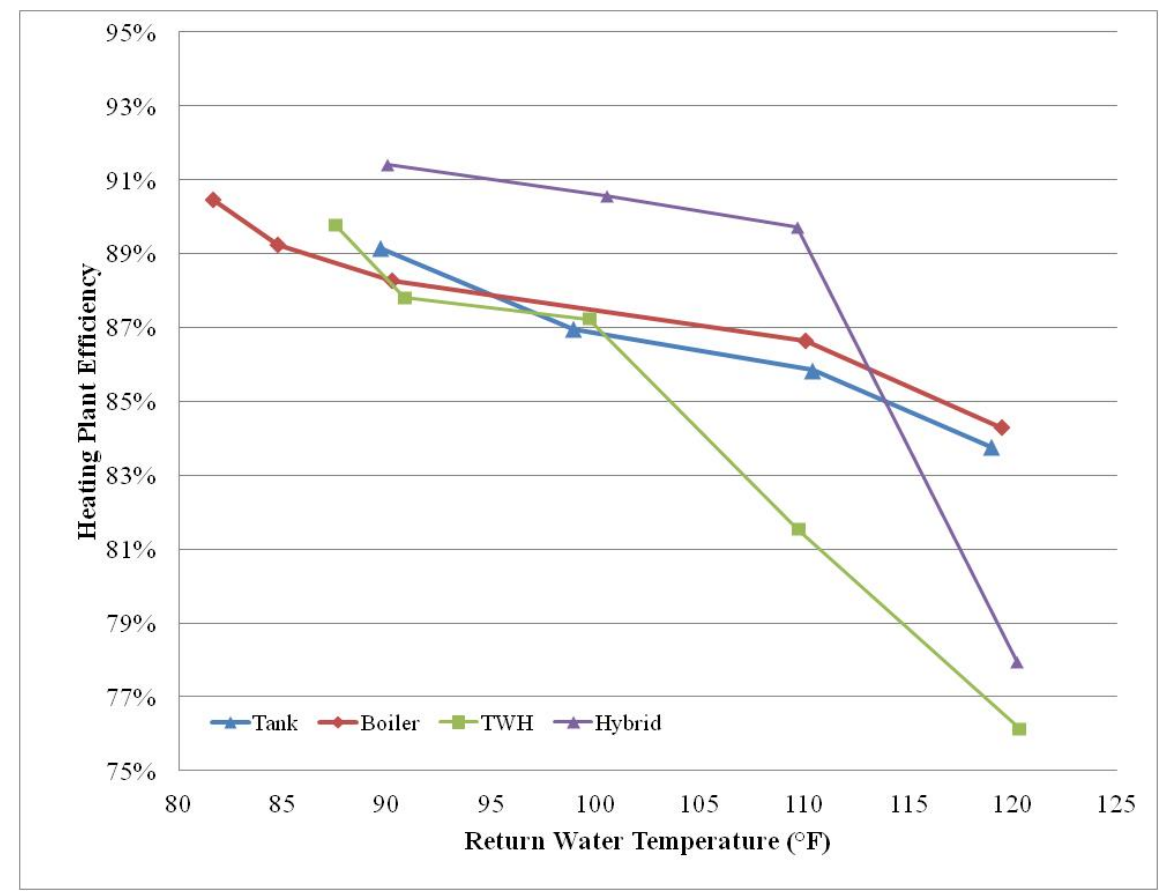

Figure 9. Impact of return water temperature on combi system efficiency under space heating operation $\left(1,000 \mathrm{CFM}^{2}\right.$ and $\left.4 \mathrm{GPM}^{3}\right)$

Optimizing heating plant operation requires an AHU coil large enough to transfer sufficient heat to meet the design load and reduce the water temperature enough to achieve high efficiency. It is also necessary to deliver supply air that is warm enough to provide comfort in the living space. In retrofit applications where duct design is difficult to alter, reducing the temperature of air blown into the occupied space increased the chance of dissatisfaction by "cold blow," and it was found that $115^{\circ} \mathrm{F}$ was an acceptable minimum supply air temperature. This temperature was comparable to the delivered supply air temperature of condensing furnaces (Brand and Rose 2012) and air source heat pumps (Johnson 2013), which are commonly installed in retrofit applications. If the air distribution system was installed or could be modified to discharge air from the diffusers that would not blow directly on people, then air temperatures could be reduced to $100^{\circ} \mathrm{F}$ or lower. Discomfort from cold blow occurred only when the movement of air was felt on skin. A lower supply air temperature would allow for a lower return water temperature and improved efficiency.

${ }^{2}$ Cubic feet per minute

${ }^{3}$ Gallons per minute 
The space heating optimization process used a return water temperature no greater than $105^{\circ} \mathrm{F}$ while maintaining an supply air temperature of $115^{\circ} \mathrm{F}$. To meet acceptable operating parameters (especially the $115^{\circ} \mathrm{F}$ supply air temperature), combi system heating capacities often exceed the required capacity to meet the home load.

The optimization process required using a surface mount thermocouple or similar device to measure the temperature of the water pipes and a second temperature measurement device to measure the supply air temperature. The process could be simplified by using an airflow measurement device and a water flow measurement instrument, but neither is required.

An iterative process was used to complete the optimization. The initial airflow was calculated from the target delivered air temperature and the design heating load using equation (1) where $\mathrm{T}_{\text {supply air }}$ is the target air temperature of $115^{\circ} \mathrm{F}$.

$$
\mathrm{CFM}=(\text { Design Heat Load }+ \text { Safety Factor }(\mathrm{Btu} / \mathrm{h})) /\left(1.08 *\left(\mathrm{~T}_{\text {supply air }}-68\right)\right)
$$

After the initial operating CFM was calculated, the iterative process shown in Figure 10 determined the optimized operating conditions. If the optimization called for changing the airflow rate, Equation 1 was solved for the supply air temperature (Equation 2) and used to determine the new target supply air temperature to ensure that the design load was met.

$$
\mathrm{T}_{\text {supply air }}=((\text { Design Heat Load }+ \text { Safety Factor }(\mathrm{Btu} / \mathrm{h})) / 1.08 *(\mathrm{CFM}))+68
$$

The new target air temperature replaced the old target of $115^{\circ} \mathrm{F}$, and the optimization continued until three conditions were met:

- The AHU output was equal to or greater than the design heating load plus a safety factor.

- The delivered air temperature at the outlet of the AHU was greater than $115^{\circ} \mathrm{F}$.

- The water temperature returning from the AHU was less than or equal to $105^{\circ} \mathrm{F}$. 


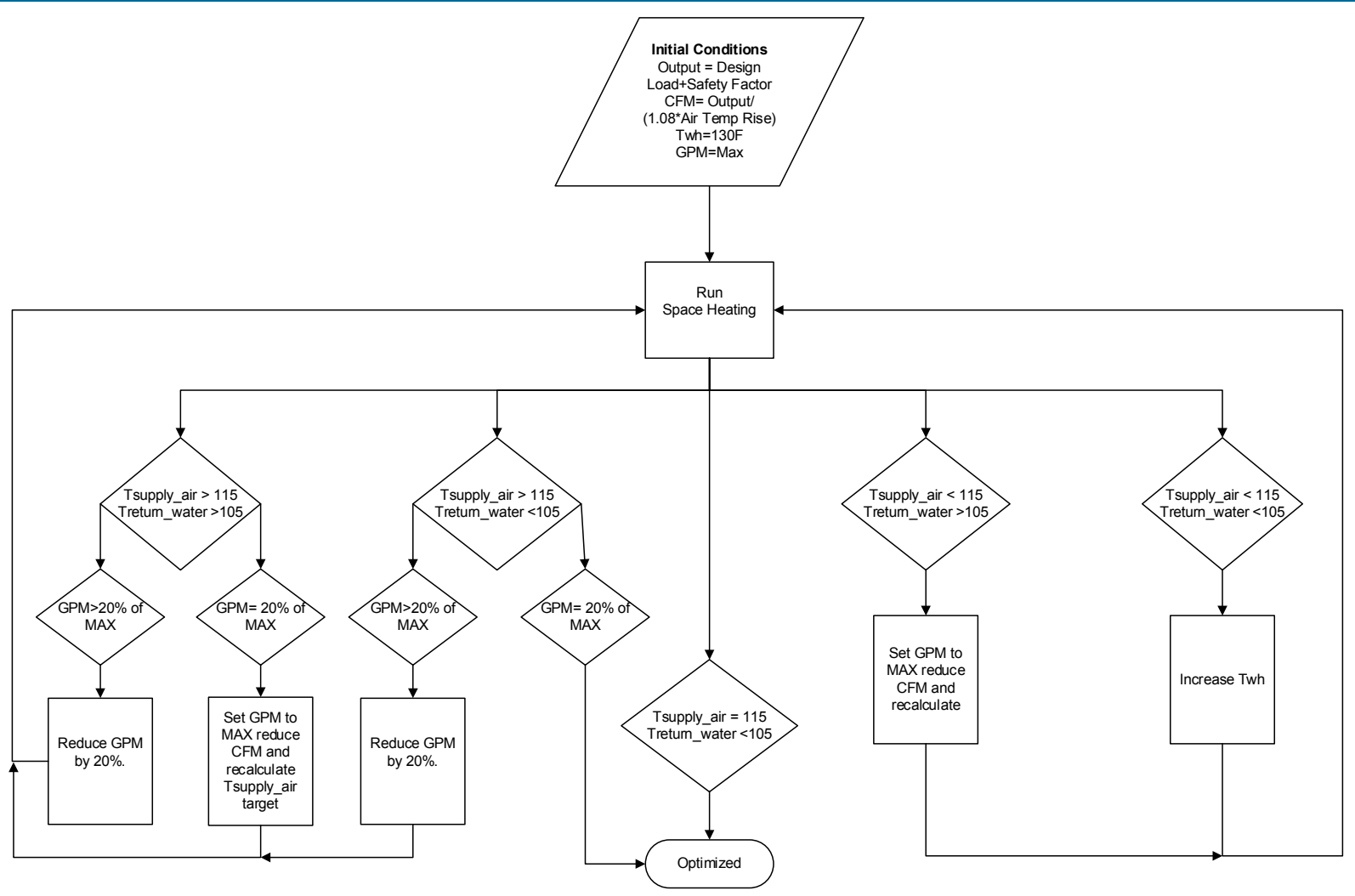

Figure 10. Air handling unit optimization process

\section{$\therefore$ No Optimization}

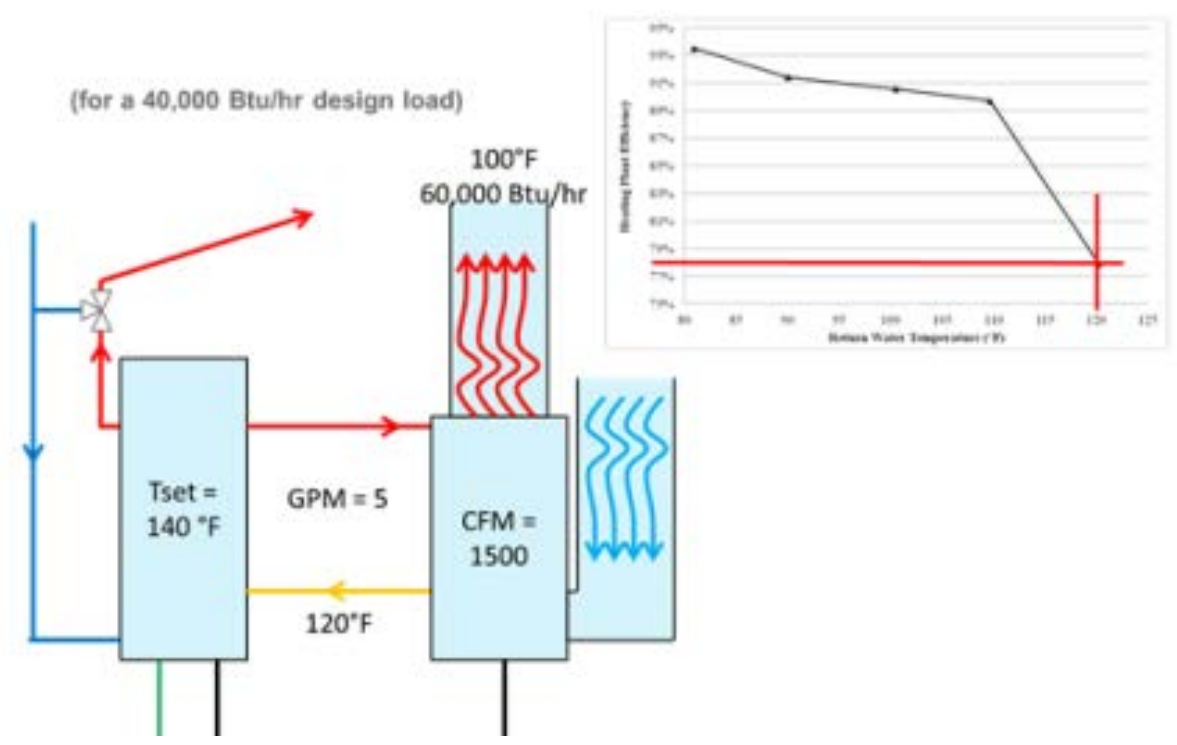

Figure 11. Combi system installed without optimization 
Figure 11 shows an example of how to set up the system for low efficiency and high heat output. In instances demonstrated in this figure, the contractor needs to decide that they want as much heat output as possible and run the AHU at the highest speed with the circulation loop balancing valve fully open for a flow rate of $5 \mathrm{GPM}$. That provides $60 \mathrm{k} \mathrm{Btu} / \mathrm{h}$, but the high rate of the water flow results in a high return water temperature. The lower the rate of the water flow, the closer the return water temperature gets to the AHU return air temperature of $70^{\circ} \mathrm{F}$.

\section{- Improved Installation}

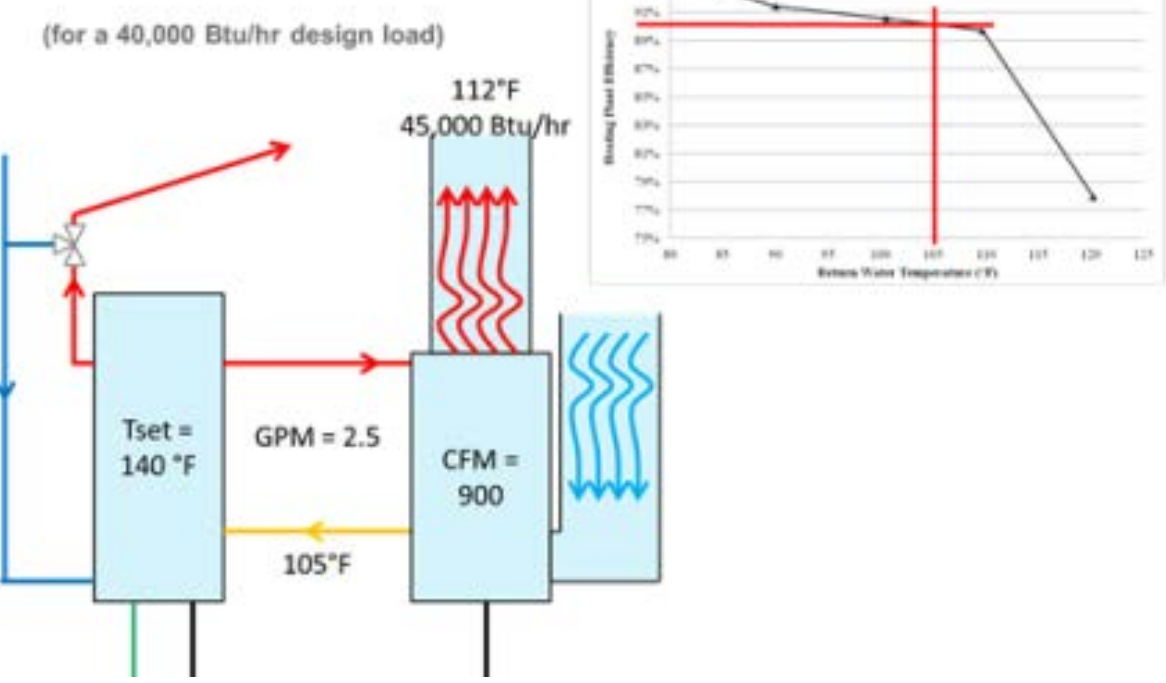

Figure 12. Combi system installed with optimization

Figure 12 shows an improvement on the no-optimization installation. In this situation, the water flow rate is reduced to $2.5 \mathrm{GPM}$ to get the return water temperature down to $105^{\circ} \mathrm{F}$, resulting in an approximate $10 \%$ increase in efficiency and boosting the performance into the condensing range that should be expected with this equipment. The system heating output is $10 \%$ greater than the design load of the home, and the lower airflow rate provides an acceptable supply air temperature of $112^{\circ} \mathrm{F}$. 


\section{Fully Optimized}

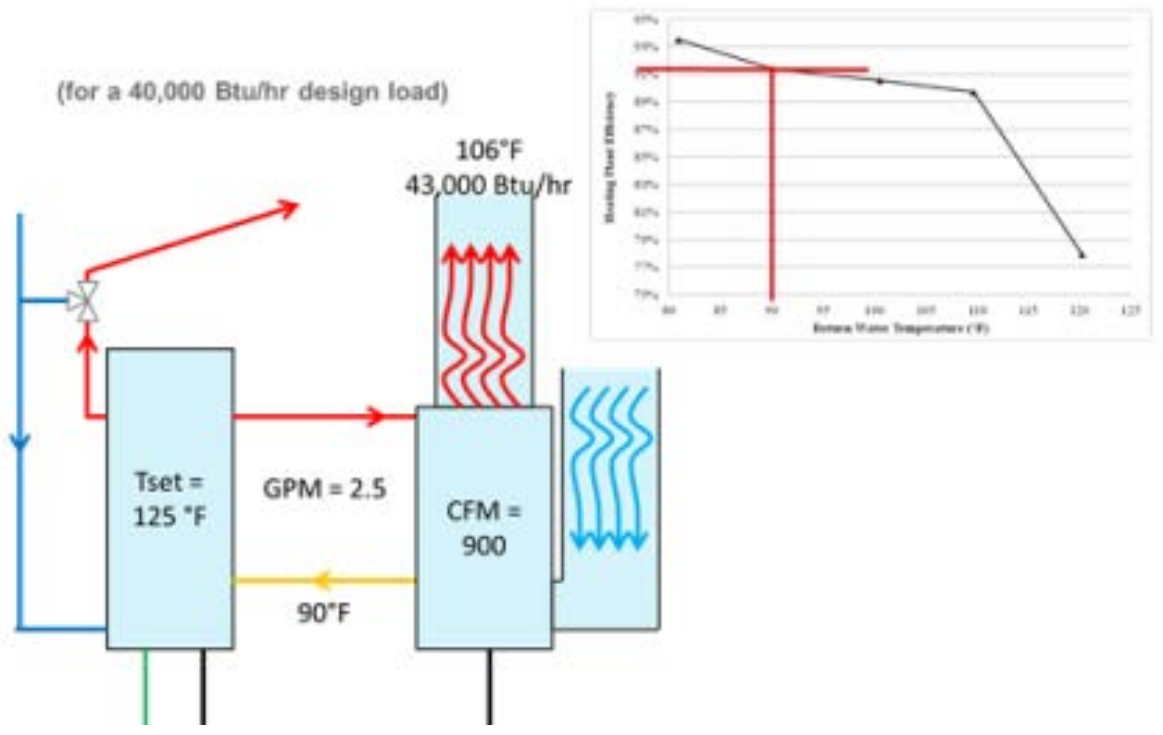

Figure 13. Combi system installed fully optimized

Figure 13 shows a fully optimized system. This setup reduces the water heater set point temperature to $125^{\circ} \mathrm{F}$, which slightly improves the steady-state efficiency. The lower tank temperature also decreases the thermal loses from any stored hot water. This adjustment results in a reduced supply air temperature of $106^{\circ} \mathrm{F}$. Air temperatures in this range are slightly lower than the $115^{\circ} \mathrm{F}$ that might be typical for condensing furnaces. However, if the supply registers are not blowing air directly in the areas people are expected to occupy, then $106^{\circ} \mathrm{F}$ may not present any comfort issues. Delivered air temperature and occupant comfort is difficult to predict and design for. Some heating systems, such as air source heat pumps, deliver supply air temperature below $110^{\circ} \mathrm{F}$, but some occupants will find this undesirable. One benefit of the flexibility of combi system operation is the ability to adjust the set points to meet the homeowner's needs.

\subsection{Operation, Control, and Maintenance}

The combi system delivers the same type of service as individual furnaces and water heaters, but there are minor differences regarding operation, maintenance, and performance.

\subsubsection{Operation and User Control}

For a traditional system, the occupant has two control points: the thermostat for space heating and the water temperature set point for DHW. The combi system thermostat operates exactly the same as a traditional furnace, and in retrofit applications the thermostat does not need to be replaced or modified. The DHW temperature control will change from a water heater set point control to a mixing valve control installed near the water heater outlet. The thermostatic mixing valves have an element inside the valve that expands and contracts in response to changes in water temperature. The expansion and contraction controls the mixture of hot and cold water to 
maintain the desired water temperature. The mixing valve also reduces the variance in water temperature coming from the water heater. Figure 14 shows the impact of the mixing valve for the StWH used in this project. The figure shows the temperature delivered by the water heater (in black) and the mixing valve (in blue) for a series of DHW events in a typical home. The events started at a time of 0 seconds, and the temperature delivered from the StWH varied from approximately $135^{\circ} \mathrm{F}$ to $145^{\circ} \mathrm{F}$. This variance was due to the dead band on the storage tank. The figure also shows a slight delay of approximately 10 seconds until the mixing value came up to temperature. This was because it was installed downstream of the water heater outlet. Once tempered, there was little variance in water temperature. Additionally, the variance from one event to another was reduced from approximately $10^{\circ} \mathrm{F}$ at the $\mathrm{StWH}$ outlet to approximately $5^{\circ} \mathrm{F}$ at the mixing valve outlet.

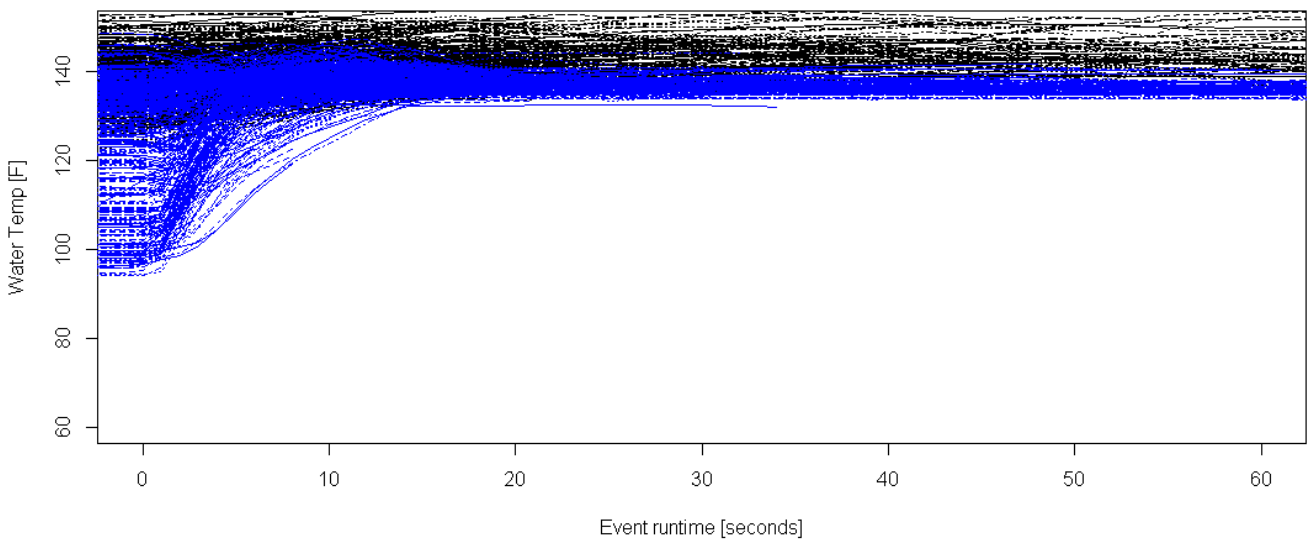

Figure 14. Hot water temperatures delivered by the water heater (black) and mixing value (blue)

\subsubsection{Maintenance}

Traditional space and water heating systems have a small list of recommend annual maintenance activities. The list for a furnace includes recommendations for an inspection and general cleaning of the burner, venting, heat exchanger, and blower fan. A furnace also requires regular filter cleaning or replacement. A traditional water heater comes with recommendations for annual inspection and cleaning of the burner and venting as well as annual flushing to clear out buildup and debris. A combi system should require less maintenance because it has only one burner, heat exchanger, and venting system, which reduces maintenance and upkeep. The AHU is also a simple system; the blower and air filters are the only aspects of the system that require regular maintenance. A higher performance combi system has slightly different maintenance and upkeep requirements than a traditional water heater, and the operation manual should be followed for all maintenance procedures. Maintenance procedures for many high-efficiency systems have improved since they were first introduced. For example, TWHs once required annual flushing, which often required a skilled technician. Most TWHs no longer require annual flushing when water quality is maintained. The flushing procedure has also been simplified so that when it is necessary it can be performed by the homeowner. In addition to reduced annual maintenance, the combi system should have increased durability. The condensing heating plants are typically 
made of more robust materials, such as stainless steel. These materials will help improve the durability and expected life of the system.

All the equipment discussed in this measure guideline is supported by the manufacturer's warranty for use in combi systems and was rated for this purpose. The equipment described had warranties comparable to other high-performance equipment, and are all expected to have good durability in delivering their intended performance. It is not advisable to install water heaters that are not intended for this type of installation by the manufacturers because some water heaters are not designed for the load profile required of a combi system.

\subsection{Metrics and Standards (Ensuring Performance)}

High-efficiency combi systems are an emerging technology, and many installers are unfamiliar with installing and optimizing the systems. Verifying proper installation was necessary to achieve the desired results of a safe, comfortable, and efficient space and water heating system. After training contractors, installing systems, and verifying installations, a three-step process was developed to verify future installations. This is outlined in Table 4. Each step of verification that is completed increases the expected performance of the system. The first step is to ensure that the correct equipment is installed. All combi systems should use approved AHUs and heating plants. Equipment can be approved by an equipment list or a set of specifications such as the following:

- All equipment must be approved for use in combined space and water heating systems.

- All heating plants should have an efficiency rating (AFUE, EF, or thermal efficiency) greater than $90 \%{ }^{4}$

- All AHUs should have a rated capacity of at least $175 \%$ of the design heating load of the home.

Because the first step ensures only that the correct equipment is used and does not address installation and optimization, this step is not sufficient to ensure optimal space conditioning performance.

The second step of the verification process is to have contractors complete combi system installation training and require that all installations be performed by trained contractors. The training should cover the installation, optimization, and operation of high-efficiency combined systems. Following this second step is crucial and will result in at least $90 \%$ of optimal efficiency.

The final step is to measure and verify the performance of the combi system, either through a documented measurement by the contractor or independent quality-control personnel. This step also includes measuring the space heating return water temperature or the combustion efficiency during a normal space heating event, which will verify that a quality installation was completed and the optimal performance of the system can be expected.

\footnotetext{
${ }^{4}$ This requirement was built based on the April 2015 ratings.
} 
Table 4. Verification Process for Installation

\begin{tabular}{|c|c|c|c|c|}
\hline \multicolumn{2}{|c|}{ Verification Measures } & \multicolumn{2}{c|}{ Expected Performance } \\
\hline $\begin{array}{c}\text { Approved } \\
\text { Equipment }\end{array}$ & $\begin{array}{c}\text { Trained } \\
\text { Contractor }\end{array}$ & $\begin{array}{c}\text { Verified } \\
\text { Performance }\end{array}$ & Space Heat & DHW \\
\hline$\checkmark$ & & & $80 \%$ of Optimal & Optimal \\
\hline$\checkmark$ & $\checkmark$ & & $90 \%$ of Optimal & Optimal \\
\hline$\checkmark$ & $\checkmark$ & $\checkmark$ & Optimal & Optimal \\
\hline
\end{tabular}




\section{Performance and Cost}

\subsection{Energy and Savings}

When properly installed and optimized, the high-efficiency combination systems analyzed for this measure guideline provided significant savings over the systems they replaced (an $80 \%$ AFUE furnace and a $0.58 \mathrm{EF}$ natural draft water heater). Figure 15 shows the percentage annual savings measured at 12 sites using the systems based on water heaters. The water heater-based combi systems saved an average of $17 \%$. The site with the highest savings (about $34 \%$ ) had an older existing furnace with a 70\% AFUE rating. The site with the lowest savings (about 3\%) replaced a condensing furnace with a 91\% AFUE rating. The ratio of DHW load to space heating load accounted for most of the variance in savings. The load ratio was a significant factor because of the difference in the space and DHW efficiencies for most systems. Analysis was not completed at 2 sites because occupancy issues prevented sufficient data collection. Additionally, 5 homes with boilers were also monitored, but the complexity of the installation and optimization yielded lower savings, and these systems were not recommended.

Table 5 shows the average installed efficiencies measured in the field (Schoenbauer et al. 2014a) and rated efficiencies for each type of system. The winter efficiencies are dominated by space heating, and the summer efficiencies are dominated by DHW use. The table illustrates the measured difference in DHW and space heating efficiencies. Despite annual efficiencies of 84\% to $90 \%$ for combi systems, the measured DHW efficiencies were around $60 \%$ for the StWH and the HWH due to actual DHW loads that were lower than that used for the efficiency rating test. The DHW efficiencies were calculated assuming an average hot water use of $42 \mathrm{gal} / \mathrm{d}$. This number was determined from the usage patterns of field-monitored systems (Schoenbauer et al. 2014a). Figure 17 shows the seasonal installed efficiencies for the combi systems. This plot demonstrates the impact of lower loads, which result in lower DHW efficiencies in the summer.

The efficiencies measured from the installed combi systems are different than the equipment's rated efficiencies (Table 5). This is because of the difference in operating conditions between the rating method and what is actually experienced in the field. This difference has been measured for conventional space and water heating systems in this project and in others (Schoenbauer 2011, Brand and Rose 2012). The high-efficiency combi systems performed the same as separately installed high-efficiency furnaces and water heaters. 


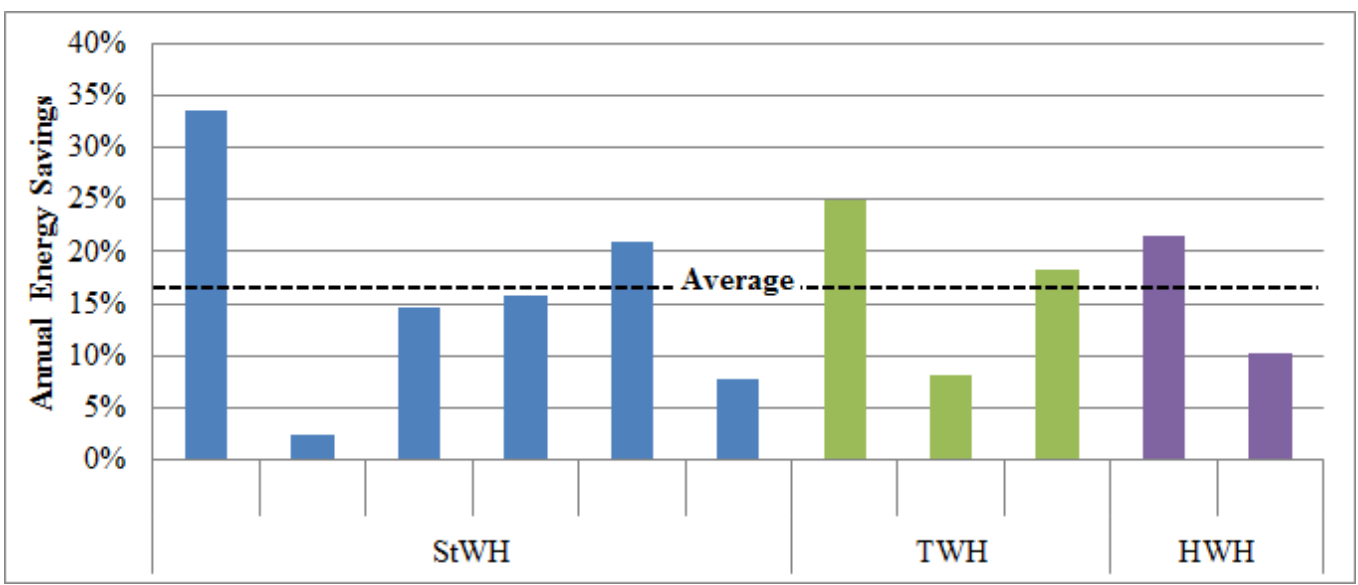

Figure 15. Energy savings from combi systems monitored in real homes

Table 5. Average Installed Performance of Combi Systems in 11 Homes

\begin{tabular}{|c|c|c|c|c|c|}
\hline \multirow{2}{*}{$\begin{array}{c}\text { Heating } \\
\text { Plant }\end{array}$} & \multicolumn{3}{|c|}{ Installed Efficiency } & \multicolumn{2}{c|}{ Rated Efficiency } \\
\cline { 2 - 6 } & Annual & $\begin{array}{c}\text { Winter } \\
\text { Space Heat }\end{array}$ & $\begin{array}{c}\text { Summer } \\
\text { DHW }\end{array}$ & Rating Method & Rating \\
\hline StWH & $86 \%$ & $87 \%$ & $60 \%$ & Thermal efficiency & $95 \%$ \\
TWH & $86 \%$ & $85 \%$ & $85 \%$ & EF & $93 \%$ \\
HWH & $90 \%$ & $92 \%$ & $61 \%$ & EF & $95 \%$ \\
Boiler & $84 \%$ & $86 \%$ & $76 \%$ & AFUE & $95 \%$ \\
Existing $^{\text {a }}$ & $71 \%$ & $72 \%$ & $47 \%$ & AFUE/EF & $79 \% / 59 \%$ \\
\hline
\end{tabular}

${ }^{a}$ Existing system efficiencies were not measured directly; they were estimated from measured energy consumption data. 

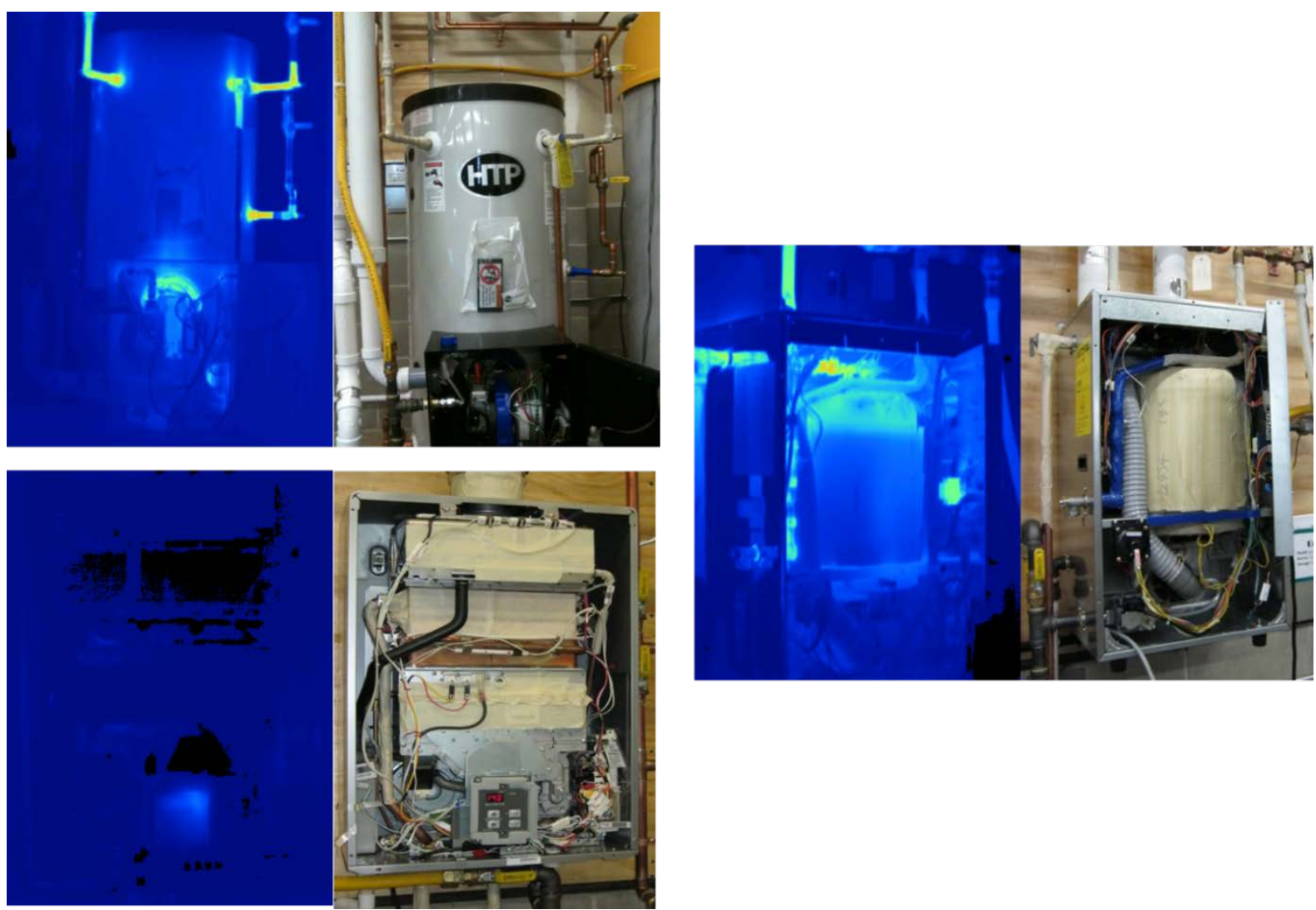

Figure 16. Infrared images of a (clockwise from top) CStWH, HWH, and CTWH in standby mode

Figure 16 shows thermal images of several heating plants including a CStWH (upper left), a HWH (right), and a CTWH (lower left). These images were taken while the heating plants were in standby and not actively producing hot water and show the areas responsible for standby heat loss. The CStWH had the largest storage capacity, but the tank was well insulated, as indicated by the relatively minor change in the infrared picture. There was some unnecessary loss due to nonexistant or inadequate heat traps on the piping and an insulation break near the burner. The images of the HWH indicate that most of its heat loss was off the top of the internal tank and the uninsulated internal piping. The CTWH did not have storage, and therefore it had no thermal heat loss requiring the burner to fire during standby. The only standby consumption was electrical to power the electronics on the water heater. 


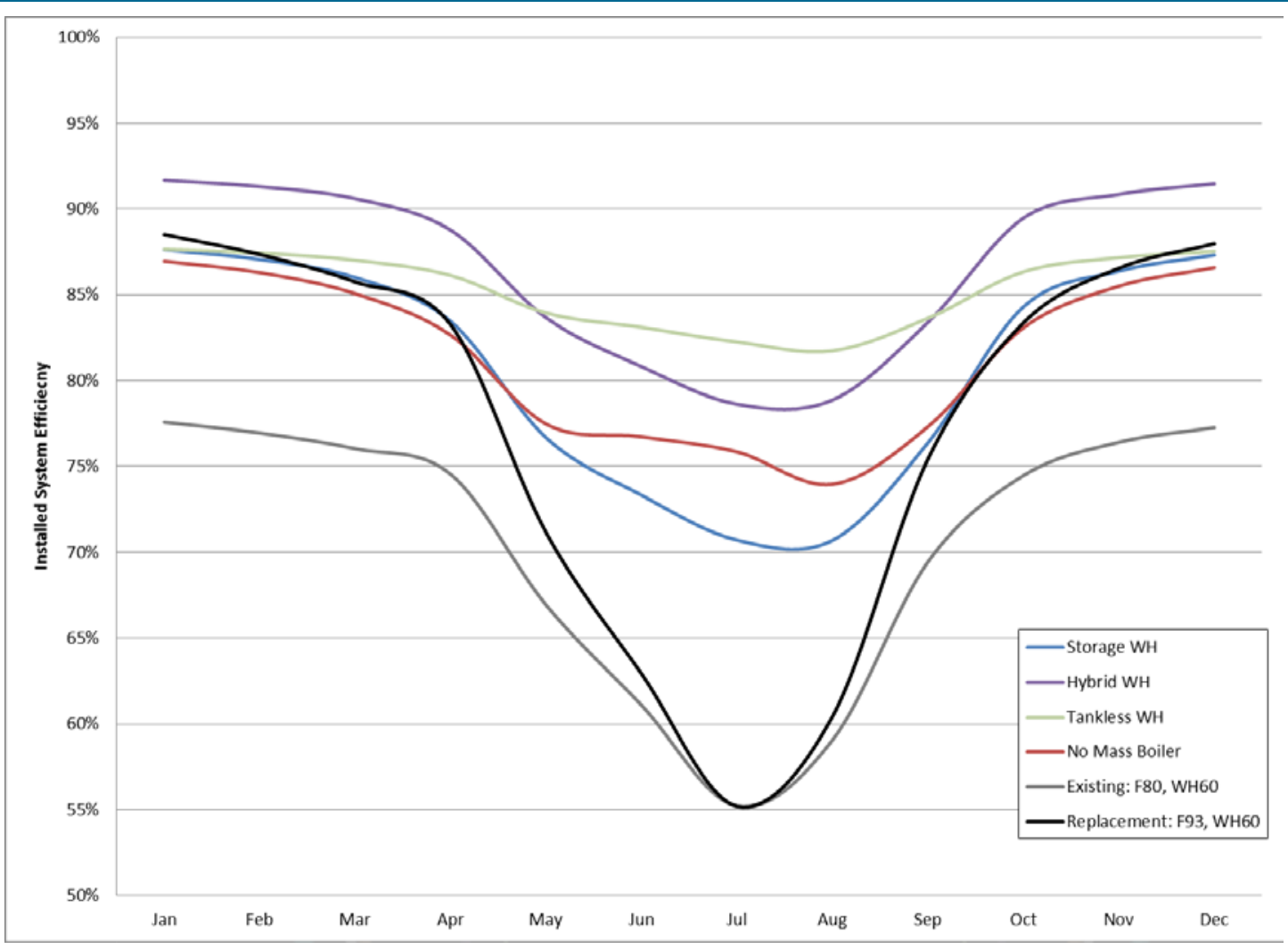

Figure 17. Seasonal operating efficiency of combi and traditional heating systems

\subsection{Cost}

Table 6 shows the average costs by system type from the 200-site Minnesota pilot program. There were differences in how the installers broke down prices by category, and it was common for several jobs with similar equipment to have similar total costs with major differences in the breakdowns among heating plant costs, labor costs, and miscellaneous materials costs. The total costs were known to be accurate and were used for cost analysis. The storage tanks were generally the most expensive to install, and tankless and hybrid systems were generally less expensive. In general, total installed cost scaled with the equipment costs.

Table 6. Average Installation Costs from Implementation Project

\begin{tabular}{c|c|c|c|c|c|c|c|c}
\hline System & No & $\begin{array}{c}\text { Heating } \\
\text { Plant }\end{array}$ & \multirow{2}{*}{$\begin{array}{c}\text { AHU } \\
\mathbf{( \$ )}\end{array}$} & \multirow{2}{*}{$\begin{array}{c}\text { Misc } \\
\mathbf{( \$ )}\end{array}$} & $\begin{array}{c}\text { Labor } \\
\mathbf{( \$ )}\end{array}$ & \multicolumn{3}{|c}{ Cost } \\
\cline { 7 - 9 } & & $\mathbf{( \$ )}$ & & & & Average & Min & Max \\
\hline Storage-Vertex & 3 & 3,223 & 2,345 & 1,280 & 1,943 & 8,792 & 8,120 & 9,505 \\
Storage-Polaris & 21 & 4,175 & 2,186 & 476 & 1,369 & 8,207 & 6,495 & 9,375 \\
\hline Storage-Phoenix & 15 & 4,397 & 2,081 & 650 & 2,479 & 9,607 & 7,135 & 11,000 \\
\hline TWH-Rinnai & 4 & 2,521 & 2,421 & 1,025 & 1,616 & 7,584 & 6,945 & 8,445 \\
\hline Hybrid-Eternal & 22 & 2,815 & 2,323 & 590 & 1,562 & 7,289 & 5,696 & 8,751 \\
Boiler-Navien & 5 & 4,129 & 2,375 & 495 & 1,124 & 8,123 & 6,650 & 8,840 \\
\hline
\end{tabular}


The installed costs of combi systems are compared to other systems types in Figure 18. Several costs were considered for this comparison. Low-income weatherization agencies in Minnesota have installed a large number of power-vented water heaters and condensing furnaces. This large volume of installations resulted in a price break for these agencies (Table 7). Local contractors were contacted for their typical pricing structures for open-market installations, and these costs were used for the analysis in this project. The least expensive space and water heating option would be a natural draft furnace and natural draft StWH. This inexpensive option is still common in some northern climate states, and it was useful for replacement comparisons. Typical costs for this base system are approximately $\$ 3,075(\$ 1,875$ for the furnace and $\$ 1,200$ for the water heater). A common system upgrade consisted of a condensing gas furnace (with an average AFUE of 94\%) and power vent water heater (EF of 0.60 ). The power vent water heater offers only a minor update in EF rating (or no upgrade in some cases). These water heaters are typically installed due to combustion safety concerns. This was the system typically installed by Minnesota low-income weatherization programs. On the open market, this system costs $\$ 6,350$ to install ( $\$ 4,250$ for a condensing furnace and $\$ 2,100$ for the water heater), which includes local utility rebates. Local weatherization paid an average of $\$ 3,500$ for a condensing furnace and $\$ 1,800$ for the water heater. A homeowner seeking high-efficiency space and water heating could install a condensing furnace and condensing StWH (thermal efficiencies of 95\%) or condensing TWH (EF of 0.92 to 0. 98\%). Open-market installation costs for a condensing StWH were found to be $\$ 5,300$, and previous research (Schoenbauer et al. 2011) showed condensing TWHs with installed costs of $\$ 4,000$. Condensing combi systems were the lowest cost method of providing both condensing water heating and space heating (Table 7). Although the costs of installing a condensing furnace and power vent water heater are lower, they provide only water heating with a $0.60 \mathrm{EF}$ rating. Contractors also had little experience with combi systems, and their costs will likely change over time if the numbers of installations increase.

Combi system equipment can currently have three different ratings-EF, AFUE, and thermal efficiency - and confusion surrounding multiple ratings has prevented local utilities from rebating combi systems. This ultimately makes combi systems a less desirable option, even though condensing furnaces, power vent water heaters, TWHs, and condensing StWHs are more mature technologies with better defined costs. 


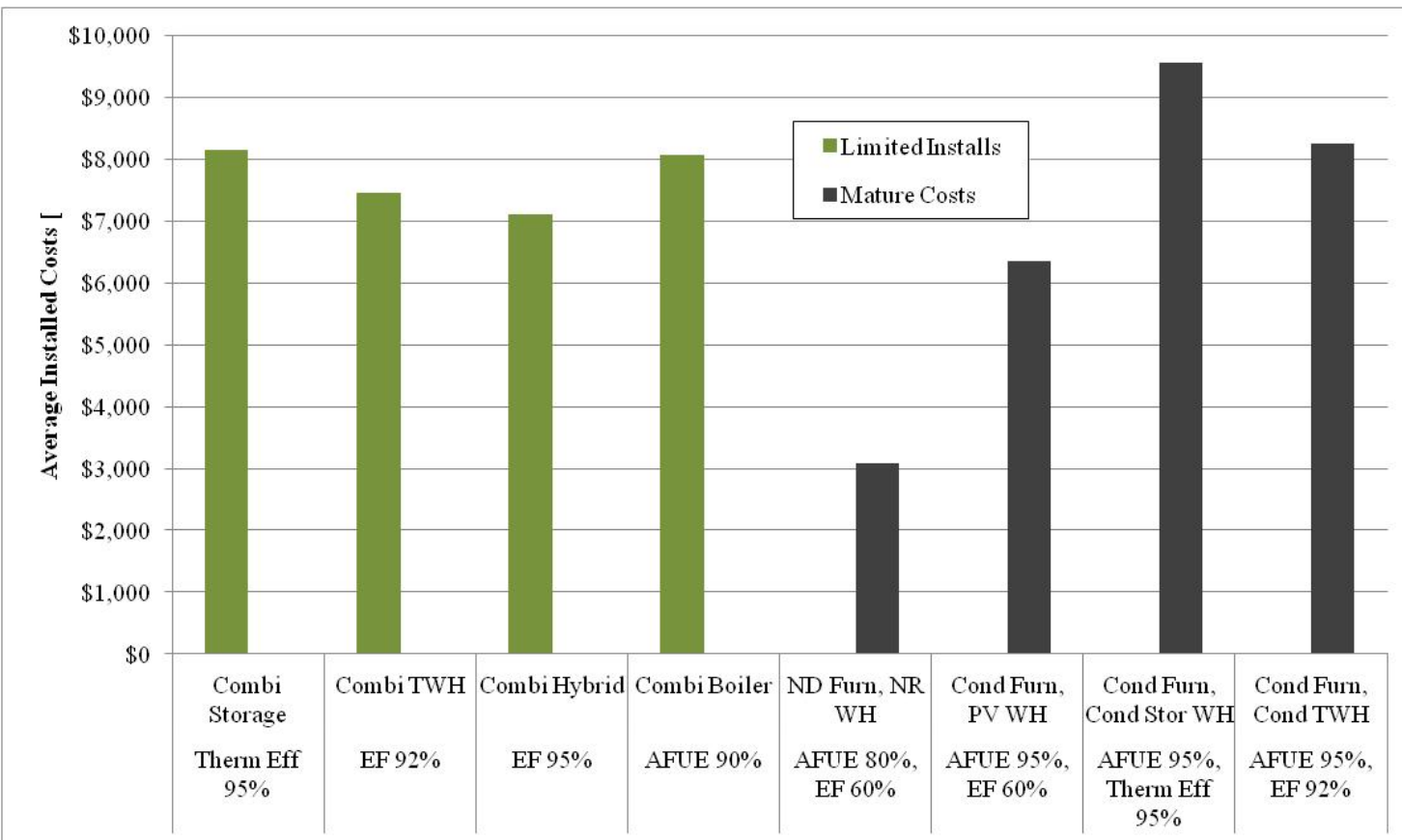

Figure 18. Installation costs for residential heating, ventilating, and air-conditioning systems

Table 7. Installation Costs for Furnaces and WHs

\begin{tabular}{c|c|c|c}
\hline & $\begin{array}{c}\text { Program or High Volume } \\
(\mathbf{\$})\end{array}$ & $\begin{array}{c}\text { Open Market } \\
\mathbf{( \$ )}\end{array}$ & $\begin{array}{c}\text { BEoptE + } \\
\text { v1.01 } \\
\mathbf{( \$ )}\end{array}$ \\
\hline Condensing Furnace & 3,500 & 4,250 & 3,318 \\
Minimum Efficiency Furnace & - & 1,875 & 1,408 \\
\hline Power vent WH & 1,800 & 2,100 & 970 \\
Condensing StWH & $5,100^{\mathrm{a}}$ & 5,350 & - \\
Condensing TWH & - & - & 1,800 \\
\hline
\end{tabular}

${ }^{\text {a }}$ Price was based on the installed cost of a power vent water heater and the increased cost of a condensing StWH.

\subsection{Delivered Performance}

\subsubsection{Delivered Air Temperature}

Delivered air temperatures for combi systems are comparable to those for other system types. Natural draft non-condensing furnaces have a preset time delay between activating the burner and turning on the fan. Figure 19 shows how standard furnaces (time equals 0 when the fan is turned on) compare to the combination systems. The furnaces have air temperatures of $125^{\circ} \mathrm{F}$ to $150^{\circ} \mathrm{F}$. Combination systems typically have air temperatures between $110^{\circ} \mathrm{F}$ and $120^{\circ} \mathrm{F}$. Other projects have shown that condensing gas furnaces typically deliver air temperature of $115^{\circ} \mathrm{F}$ to $130^{\circ} \mathrm{F}$. Heat pump systems have air temperatures of $77^{\circ} \mathrm{F}$ to $115^{\circ} \mathrm{F}$ (Natural Resources Canada 2009). These systems have had significant numbers of installations without complaints about occupant comfort. 


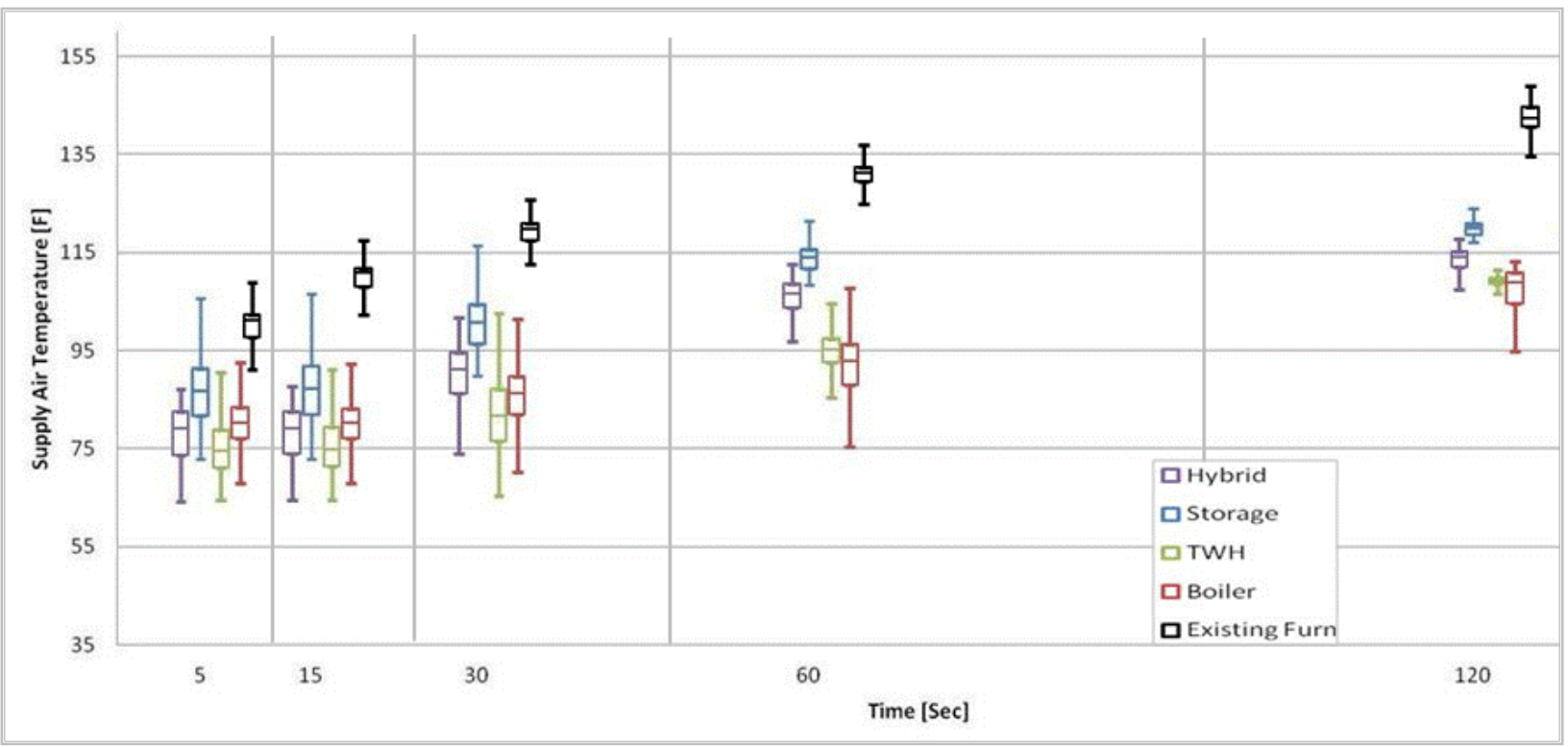

Figure 19.Time series discharge air temperatures for combi systems

\subsubsection{Delivered Water Temperature}

Figure 20 shows hundreds of traces of the change in hot water from the water heaters at the start of a draw. The red horizontal line at $140^{\circ} \mathrm{F}$ indicates the set point temperature that was used for most of the units, the black vertical line designates the start of the draw, and the green vertical line designates 10 seconds into the draw. For the storage water heaters, the temperature comes up within a few seconds, and it generally comes up within 10 seconds for the hybrid system. However, the tankless unit can take 20 to 30 seconds for the temperature to come up. It is also interesting to note the wide temperature band for the standard storage water heater. These heaters have a very wide dead band of $20^{\circ} \mathrm{F}$ or more, which shows the wide variation in outlet temperature from one draw to the next for a typical StWH. 

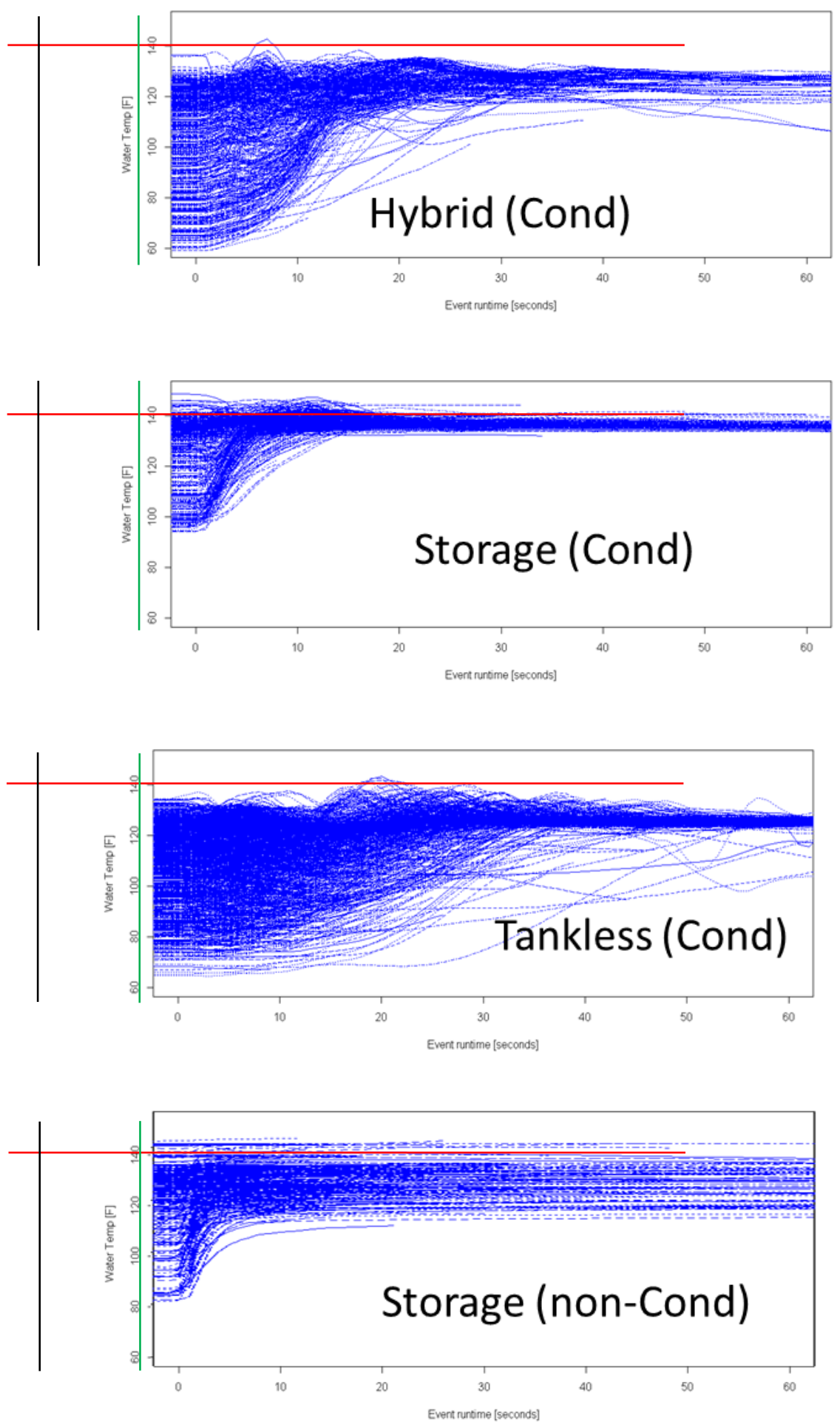

Figure 20.Time series DHW outlet temperatures for combi systems 


\section{Future Considerations}

Two major areas consideration in the future of combination systems: new developments in equipment and changes to regulations, rating methods, and standards. Both areas are poised for significant advancement and improvement. Small, quick-responding manufacturers and large international companies have shown interest in combi systems, and manufacturers are currently designing and developing new equipment. When it comes to standards and regulations, there is currently no required method in the federal register to test combi systems. Equipment is rated as a water heater or a boiler, and its operation as part of a forced-air heating system is not considered.

\subsection{Equipment}

Water heater manufacturers are developing new products. Several manufactures are developing HWHs to improve capacities, reduce costs, and improve occupant satisfaction. Several of these units have been developed with higher capacity burners that can be used with $1 / 2$-in. gas lines.

- Eternal: 2-gal 18,000 Btu/h to $120,000 \mathrm{Btu} / \mathrm{h}$ burner on $1 / 2$-in. gas line

- Eternal: 20-gal fixed 100,000 Btu/h Btu/h burner on 1/2-in. gas line

- Rinnai: 40-gal 59,500 Btu/h to 91,200 Btu/h burner on 1/2-in. gas line

- Navien: 1/2-gal 19,000 Btu/h to 199,000 Btu/h burner on 1/2-in. gas line.

There are also hydronic AHUs on the market that include integration with another highperformance system such as heat recovery ventilation. Rheem has a unit that has a modulating pump and fan. This unit automatically optimizes its operation for any installation, which eliminates a lot of time and difficulty during the installation.

- NuAire: AHU and heat recovery ventilation integration

- Rheem: RHWB AHU: Modulating pump and fan.

\subsection{Standards}

Work is continuing on the update to the ASHRAE 124 method to test combi systems. It is hoped that the new version will include a method for integrated systems. The ultimate goal is to establish a method of test that the industry will use to identify high-efficiency systems. 


\section{References}

Arena, Lois. 2011. "Building America Systems Evaluations: In-Field Performance of Condensing Boilers in Cold Climate Region." Steven Winters Associates, Inc.

Bohac, D.; Hewett, M.; Dunsworth, T.; Hancock, M.; Staller. T. 1991. Retrofit Savings for Dual Integrated Appliances in Small Commercial and Multifamily Buildings. Report to Minnegasco, Inc. Center for Energy and the Urban Environment. www.mncee.org/pdf/tech pubs/90-5.pdf.

Brand, L.; Rose, W. 2012. Measure Guideline: High Efficiency Natural Gas Furnaces. (Technical Report). Golden, CO: National Renewable Energy Laboratory.

Butcher, Thomas. 2011. "Performance of Combination Hydronic Systems." ASHRAE Journal 53 (12): 6 .

Johnson, R.K. 2013. Measured Performance of a Low Temperature Air Source Heat Pump. (Technical Report). Golden, CO: National Renewable Energy Laboratory. http://apps1.eere.energy.gov/buildings/publications/pdfs/building_america/low_temp_air_source heat pump.pdf.

Natural Resources Canada. 2009. "Air Source Heat Pumps.” Office of Energy Efficiency. April 20. http://oee.nrcan.gc.ca/publications/residential/heating-heat-pump/4608.

Rudd, Armin. 2010. "Building America Special Research Project: Space Conditioning Systems for High Performance Home.” Research report 1009. Building Science Corporation.

Schoenbauer, Ben; Bohac, David; Huelman, Patrick; Olson, Rebecca; Hewett, Martha. 2012. Retrofitting Combined Space and Water Heating Systems: Laboratory Tests. (Technical Report). Golden, CO: National Renewable Energy Laboratory. http://www.nrel.gov/docs/fy13osti/55482.pdf.

Schoenbauer, Ben; Bohac, David; Huelman, Patrick; McAlpine, Jake. 2014a. Retrofitting Combined Space and Water Heating Systems: Field Assessment. (Technical Report). Golden, CO: National Renewable Energy Laboratory.

Schoenbauer, Ben; Bohac, David; McAlpine, Jake. 2014b. "Why Pay for Two Condensing Systems When One Will Do?" In 2014 ACEEE Summer Study on Energy Efficiency in Buildings Proceedings. Asilomar, CA: ACEEE. http://www.aceee.org/conferences/2014/ssb.

Schoenbauer, Ben; Hewett, Martha; Bohac, David. 2011. "Actual Savings and Performance of Natural Gas Instantaneous Water Heaters.” ASHRAE Transactions 117 (Part 1): 657-72.

Thomas, Martin. 2011. "Combination Systems Good or Bad?" presented at the ACEEE Hot Water Forum, Berkeley, CA, May 11. http://www.aceee.org/files/pdf/conferences/hwf/2011/7A\%20-\%20Martin\%20Thomas.pdf. 
